\author{
WOJCIECH CHUDZIAK, MARCIN WEINKAUF, EWELINA SIEMIANOWSKA, \\ JACEK BOJARSKI, BARBARA KOWALEWSKA, PAWEŁ SZCZEPANIK, \\ JOANNA ABRAMÓW, DOROTA BIENIAS, DANIEL MAKOWIECKI
}

\title{
DOMNIEMANA KARCZMA Z WCZESNOŚREDNIOWIECZNEGO ZESPOŁU OSADNICZEGO W KAŁDUSIE NA POMORZU NADWIŚLAŃSKIM
}

\author{
THE SUPPOSED INN FROM EARLY MEDIEVAL SETTLEMENT COMPLEX \\ IN KAŁDUS ON POMERANIA VISTULA
}

The paper concerns one of the construction discovered within the early medieval, immediately adjacent to a fortified centre, ancillary settlement in Kałdus (historical Chełmno), which has been interpreted as remains of a supposed inn. It includes formal analysis of the construction and of movable objects found within, carried out in comparison with the results of studies over the spatial and functional layout of the settlement. The analysis was carried out in the context of theoretical knowledge on medieval inns, and especially of the content of the so-called Mogilno forgery, where nonum forum cum tabernario in Culmine was mentioned.

KEY WORDS: structures of settlement, communications, inn, early middle ages, Pomerania Vistula

\section{WPROWADZENIE W PROBLEMATYKĘ}

W przestrzeni społeczno-kulturowej wczesnośredniowiecznej Europy szczególne miejsce zajmowały karczmy stanowiące jeden z głównych elementów ówczesnej infrastruktury komunikacyjnej (por. szerzej Gastfreundschaft 1983; Peyer 1987; Le Goff 2002, 379; Constable 2004) ${ }^{1}$. Na terenie

\footnotetext{
1 Artykuł powstał w oparciu o sesję zespołu autorskiego pt. The Early Medieval Inn in Culmine: How Pleasure and U sefulness Were J oined Together in Ancient Poland przedstawiona podczas International Medieval Congress w Leeds 2 lipca 2013 roku. Zaprezentowano wówczas na-
}

byłego Barbaricum pojawiły się one znacznie później niż na obszarze zachodnioeuropejskim czerpią-

stępujące referaty: Relics of the Inn at Culmine (P. Szczepanik), Building Reconstruction and Spatial Organization (B. Kowalewska) oraz F unctions of the Inn in the Light of Archaeological and Written Sources (E. Siemianowska). Opracowanie niniejsze zostało przygotowane $\mathrm{w}$ ramach grantu NCN nr 2011/03/B/HS3/04551 pt.: Wczesnośredniowieczny zespót osadniczy w Katdusie - chetmiński sedes regni principales (projekt 4), realizowanego pod kierownictwem prof. dr. hab. W. Chudziaka. 
cym w tym zakresie z tradycji antycznej (rzymskie mansio). Pochodzące z obszaru Słowiańszczyzny źródła dyplomatyczne datowane na XII i XIII stulecie określają karczmę najczęściej łacińskim terminem taberna lub słowiańskim korczma, ukazując ją jako instytucję już w pełni ukształtowaną i zorganizowaną. Domyślać się zatem można wcześniejszej genezy tego rodzaju obiektów, co najmniej XI-wiecznej i jej ścisłych związków z rozwojem organizacji gospodarczej państw środkowoeuropejskich. W przypadku ziem polskich i czeskich wskazują na to informacje przekazane przez Anonima tzw. Galla i czeskiego Kosmasa (Cieśla 1958, 164165; Rabęcka-Brykczyńska 1964, 373-374)², zaś w przypadku państwa ruskiego pośrednio - rozwój największych ośrodków handlowych, takich jak Kijów czy Nowogród (Pryžov 1868, 34). Wcześniejszego funkcjonowania karczem poza środowiskiem słowiańskim domyślać się można w oparciu o inskrypcję runiczną umieszczoną na kamieniu znalezionym w Karberdze niedaleko Uppsali w Szwecji (U 996; zob. Jesch 2008, 131), datowanym na przełom X i XI wieku. Użyty tam termin 'sáluhús' daleki jest od jednoznaczności: dosłownie oznacza bowiem 'dom dusz', a thumaczony może być jako schronisko i w tym konkretnym przypadku łączony z chrześcijańskim miłosierdziem wobec podróżnych (Wessén, Jansson 1953-57, 167-172; Jesch 2008, 131; Page 2014, 57).

W świetle źródeł pisanych funkcjonowanie karczem w większych ośrodkach targowych we wczesnym średniowieczu przyjmowane jest tak przez historyków jak i archeologów niejako za oczywiste (por. np. Trawkowski 1962; Buczek 1964, 69-79; Dembińska 1978a, 252-253; Moździoch 1990, 160185; Pauk 2015, 97-98). Wbrew jednak postulatom głoszonym w latach 50. minionego stulecia przez Irenę Cieślową (Rabęcką-Brykczyńską), autorkę podstawowego opracowania tego zagadnienia (Cieśla 1958), usiłującą zwrócić uwagę archeologów na tego rodzaju obiekty i potrzebę ich identyfikacji w materiale źródłowym, studia archeologiczne nad

2 „Boleslavo [Chrobry - przyp. autorów] ergo rege de mundana conversatione descedente (...) nullus plausus, nullus cytharae sonus audiebathur in thabernis", Anonim tzw. Gall, I, 16; "Tabernam (...), que est radix omnium malorum, unde prodeut furta, homicidia, adulteria et cetera mala, et qui parat et qui paratam comparat, Severus episcopus dixit: Anathema sit” Kosmas, II, 3; por. też odnośnie do przekazu Kosmasa ostatnio Pauk 2015. tym zagadnieniem stanowią nadal margines $\mathrm{w}$ całokształcie problematyki osadniczej i społecznogospodarczej ziem polskich we wczesnym średniowieczu. Spowodowane jest to przede wszystkim lakonicznym charakterem przekazów pisanych, które nie tylko nie podają wskazówek dotyczących dokładniejszej lokalizacji wzmiankowanych karczem, ale i nie pozwalają na wyszczególnienie cech typowych dla budynków użytkowanych w ten sposób (por. np. Barciak, Sepiał 2011, 52, ryc. 1; Augustyniak 2014, 169-171). Brak również w źródłach pisanych jakichkolwiek informacji o wyglądzie, wielkości, technice konstrukcji ścian czy innych istotnych elementach, które byłyby przydatne przy identyfikacji odkrywanych podczas badań archeologicznych reliktów budynków i wskazaniu, które z nich mogą stanowić pozostałość karczem. Złożoność problemu związana jest również z faktem, że w okresie tym na obszarze Europy Środkowej, a w szczególności północnej części Słowiańszczyzny Zachodniej, większość budynków bez względu na ich funkcję wznoszonych było $\mathrm{z}$ drewna, $\mathrm{z}$ reguły słabo zachowującego się w podłożu mineralnym (por. Gupieniec 1999).

Głównie z tych powodów identyfikacja pozostałości karczem w Europie Środkowej i Północnej należy generalnie do sytuacji wyjątkowych (Moździoch 2013, 125; Söderlind 2007; por. też Drury 1988, 5-42; Munby et al. 1992). Do niedawna z obszaru współczesnych ziem polskich dla okresu wczesnego średniowiecza istnienia tego rodzaju obiektów domyślano się na podgrodziu Ostrowa Tumskiego w Poznaniu (Hensel 1958, 151) oraz Ostrowa Tumskiego we Wrocławiu (3. ćwierć XI wieku; Kaźmierczyk 1993, 124-133). Ostatnio budynek interpretowany $\mathrm{w}$ ten sposób datowany na 2. połowę XII i początek XIII wieku odkryto również na osadzie podgrodowej w Wyszogrodzie, w bezpośrednim sąsiedztwie reliktów bramy wjazdowej (Bojarski, Chudziak, Weinkauf w druku a) ${ }^{3}$. Interpretacja ta znajduje swoje potwierdzenie w dokumencie z 1145 roku, w którym w kontekście gro-

3 W trakcie badań prowadzonych w 2012 i 2013 roku w Bydgoszczy Wyszogrodzie zadokumentowano relikty dużego budynku (obiekt 24) o wymiarach znacznie przekraczających ówczesne standardy wielkościowe (powierzchnia około $30 \mathrm{~m}^{2}$ ), który wstępnie uznano za pozostałość karczmy. Obiekt wyróżniał regularny czworokątny kształt, podpiwniczenie oraz znajdujący się od strony wschodniej korytarz. 
du wyszogrodzkiego wymieniono komorę celną, targ i właśnie karczmę (Guldon, Powierski 1974, 66-67). W literaturze natknąć się można również na informacje o podobnych odkryciach $\mathrm{z}$ okresu późnośredniowiecznego, a zwłaszcza nowożytnego (Waluś, Manasterski 1999, 207; Suchanecka 2011, 260-261); są to wszakże wzmianki tak skąpe, iż nie wiadomo, jakimi kryteriami kierowano się przy ich identyfikacji. Tylko niektóre obiekty doczekały się pełnej publikacji. Z obszaru współczesnej Polski dysponujemy nielicznymi opracowaniami karczem: jednej późnośredniowiecznej ze Strzelec Krajeńskich (pow. loco) oraz dwóch nowożytnych z Dubna (pow. Bielsk Podlaski) i Komorowa (pow. Szamotuły) (Andrzejewski 2013, 149-155; Andrzejewski, Karwowska 2013, 362-364, 367; Komorowo 1999; Pytlak, Pytlak 2014) ${ }^{4}$. Jedynie w odniesieniu do obiektu z Dubna wyniki badań archeologicznych potwierdzone zostały przez źródła pisane, a dokładnie przez inwentarze dóbr dworu dubieńskiego z lat 1646, 1655 i 1662, jak również pośrednio przez niemieckie i rosyjskie materiały kartograficzne z końca XIX i początku XX stulecia (Andrzejewski, Karwowska 2013, 362). Funkcję pozostałych domniemanych karczem ustalono natomiast w oparciu o przesłanki stricte archeologiczne, takie jak ich lokalizacja (przy ciągach komunikacyjnych), rozmiary (zdecydowanie większe niż przeciętne współczesnych im budynków) i specyfika ruchomego materiału źródłowego (liczne fragmenty ceramiki i szczątki pokonsumpcyjne; tylko w przypadku obiektu z Wrocławia - waga szalkowa oraz odważniki) (Kaźmierczyk 1993, 124-133; Malinowski 1999; Pytlak, Pytlak 2014, 143; por. też Pearce 2000). Interesujące jest natomiast, biorąc pod uwagę ikonografię, opisy etnograficzne czy nielicznie do dziś zachowane budynki, że wymienione obiekty nie posiadały tak charakterystycznego dla karczem elementu architektonicznego, jakim były podcienie wydatnie powiększające ich zadaszoną przestrzeń użytkową (Gloger 1910, 11, ryc. 3-4; Baranowski 1979, 17-20, ryc. 9-12, ryc. za tekstem 1-11; Szurowa 1978, 68, 86; por. karczmy

${ }^{4}$ Zabytki szklane z karczmy w Dubnie oraz domniemana karczma w Strzelcach Krajeńskich stały się przedmiotem prac magisterskich napisanych w Instytucie Archeologii UMK w Toruniu pod kierunkiem dr hab. K. Sulkowskiej-Tuszyńskiej, prof. UMK (Ojdana 2012; Pytlak 2013). w Sławkowie i Jeleśni, woj. śląskie czy w Suchej Beskidzkiej, woj. małopolskie).

Pewnym utrudnieniem w rozpoznaniu wczesnośredniowiecznych karczem jest również to, iż pełniły one o wiele bardziej złożone funkcje gospodarcze i społeczne, niż zdaje się to sugerować etymologia słowa „karczma” ('mocny trunek, napój oszałamiający'; Sławski 1958, 73-74) wskazująca głównie na jej zadania konsumpcyjne (Samsonowicz 1954, 29; Cieśla 1958; Buczek 1964, 69-79). W źródłach średniowiecznych zakres znaczeniowy terminu „taberna” był o wiele szerszy, choć odnosił się przede wszystkim do „miejsc, gdzie wyrabia się i sprzedaje artykuły spożywcze i wyroby rzemieślnicze, gdzie też z konsumpcją połączona jest zabawa" (Rabęcka-Brykczyńska 1964, 18). Jedną $\mathrm{z}$ jej dodatkowych funkcji było zapewnienie noclegu przybywającym w dni targowe, co warunkowało jej lokalizację w sąsiedztwie targu i blisko głównej drogi. W dni nietargowe karczma sama odgrywała rolę targu, w niej odbywała się wymiana lokalna i ponadlokalna. Ponadto karczmarz zajmował się produkcją artykułów takich jak piwo, miód czy chleb, które następnie sprzedawał. Przypuszczalnie wykonywał też niektóre powiązane $\mathrm{z}$ karczmą rzemiosła, jak np. rzeźnicze, szewskie, krawieckie, a przede wszystkim te związane z transportem: kowalskie, kołodziejskie, co wymagało dodatkowych pomieszczeń oraz odpowiednich narzędzi, a także umiejętności. Z karczmą często łączyła się sprzedaż soli, przewóz wodny oraz komora celna, z której cło pobierać mógł też karczmarz, choć zazwyczaj trudnił się tym mincerz, kontrolujący obrót monetarny. Wszystkie te czynności podejmowano w imieniu księcia lub klasztoru, który posiadał nadania $\mathrm{z}$ dochodu z karczem i ceł, stąd zarówno karczmarz, jak i mincerz powinni być postrzegani jako oficjalni przedstawiciele władzy (por. Modzelewski 2000, $113 \mathrm{i} \mathrm{n}$.). Z pewnością ogłaszali oni nowe rozporządzenia podczas targu, który był najodpowiedniejszym ku temu miejscem $\mathrm{z}$ uwagi na zgromadzenie dużych grup ludności. Jako urzędnicy strzegli oni też porządku (miru) gwarantowanego przez władzę (Grodecki 1921; Cieśla 1958, 172-199). Wreszcie - uczestnictwo w targu czy wymianie i konsumpcji w karczmie sprzyjały rozrywce oraz spotkaniom z przyjezdnymi, co z pewnością przyczyniało się do przekazywania informacji, wiedzy o świecie jak i nowinek, np. technologicznych. Z uwagi na jej ludyczny charakter karczmę należy definiować również jako centrum kulturalne, którą to rolę peł- 
niła ona na wsi polskiej jeszcze w XIX i XX wieku (Cieśla 1958, 199-220; Zaremska 1997). Ze względu na złożoność omawianych funkcji - uzasadniony wydaje się pogląd wyrażony niegdyś przez I. Cieślę - że karczmy musiały składać się z trzech zasadniczych części, tj. budynku, zagrody i gospodarstwa, co może stanowić istotną wskazówkę w studiach nad ich rozplanowaniem (Cieśla 1958, 187). Wynikałoby z tego, że poszukiwania tego rodzaju obiektów nie można sprowadzać do lokalizacji samego budynku karczmy, ale również uwzględniać należy jej najbliższe zaplecze gospodarcze, funkcjonalnie $\mathrm{z}$ nią powiązane.

Warto również zwrócić uwagę na jeszcze jedną kwestię. Historycy już dawno stwierdzili ścisły związek karczmy i targu z mostami, brodami oraz przewozami (Dąbkowski 1914, 200-201), a konstatacja ta doskonale wpisuje się $\mathrm{w}$ obserwacje poczynione przez geografów i socjologów. Karczmy lokowano przy drogach bądź innych punktach istotnych z perspektywy transportu - skrzyżowaniach, przejściach przez bariery geograficzne, np. góry, przewłoki, rzeki (vide wspomniany wcześniej obiekt z kamienia z Karbergi), czyli tam gdzie dochodziło do styku różnych rodzajów komunikacji, która to właściwość postrzegana jest jako typowa dla początkowych faz rozwoju systemów transportowych (Cooley 1894, 91-98; Berezowski 1975, 24; Krzyżanowski 1957, 302). Konieczność zaistnienia przerwy handlowej podczas transferu dóbr (stąd break in transportation theory $\mathrm{w}$ ujęciu Ch. H. Cooley'a) generowała przeważnie po- wstanie węzła komunikacyjnego oraz specyficznej struktury zawodowej związanej właśnie z obsługa transportu (Cooley 1894, 92-93; Christaller 1963, 14; Burghardt 1971, 284; w odniesieniu do ziem polskich w okresie średniowiecza - Samsonowicz 1974, 294), w tym naprawy uszkodzonych wozów lub wymianę zepsutych jego elementów (Robak 2009, 180).

W rezultacie w punktach tych, umożliwiających „przerwę w transporcie” i z natury rzeczy idealnie nadających się do powstawania karczem, mogły wykształcić się ośrodki określane jako bramne lub miasta-wrota (gateway cities) nastawione przede wszystkim na wymianę dalekosiężną, przy niemałym udziale lokalnych transakcji. Powstawały one w strefie kontaktowej pomiędzy dwoma różnymi homogenicznie - o innej intensywności lub typach produkcji - obszarami, służąc eo ipso jak zwornik łączący różne strefy gospodarcze, geograficzne czy polityczne (Burghardt 1971, 269-270; Krzysztofik 2004).

Wobec wielofunkcyjnego, instytucjonalnego wręcz, znaczenia karczem w strukturach osadniczych i społeczno-gospodarczych, lokalizowane one były, podobnie jak targi, przy ośrodkach grodowych omawianego typu (gateway cities), w ścisłym związku z ówczesną siecią komunikacyjną (Trawkowski 1985, 110-111; Kowalczyk 1986, 6667). Najprawdopodobniej co najmniej od XII-XIII wieku każdy większy ośrodek posiadał nawet kilka tabern, z czasem zaś ich istnienie stało się regułą w każdej niemal wsi (Piskorski 2005, 35; Bojanowska-Ziemska 1978, 5, 35-36).

\section{KARCZMA Z CHEŁMNA W ŚWIETLE STUDIÓW NAD GENEZĄ I FUNKCJA WCZESNOŚREDNIOWIECZNEGO ZESPOŁU OSADNICZEGO W KAŁDUSIE}

Wśród wielu wzmianek na temat karczem z terenu ziem Polski występujących w źródłach pisanych jedna odnosi się expressis verbis do wczesnośredniowiecznego Chełmna leżącego na ziemi chełmińskiej. Jest to krótki zapis zawarty $\mathrm{w}$ tzw. falsyfikacie mogileńskim, którego adresatem był klasztor benedyktyński w Mogilnie. Dokument miał być rzekomo wystawiony w Płocku w 1065 roku przez Bolesława Szczodrego, jednak historycy przesuwają datę jego powstania na połowę XII wieku (1146 lub 1147 r.), a dokładnie na okres panowania Bolesława Kędzierzawego, zgadzając się jednak, że może on odzwierciedlać sytuację o kilka- dziesiąt lat wcześniejszą (Labuda 1978, 27-37; Bieniak 1996, 39). Wśród wymienianych w dyplomie obciążeń na rzecz klasztoru benedyktynów w Mogilnie pojawia się dziewięcina targowa $\mathrm{z}$ opłatą od karczmy w Chełmnie, w oryginale: In Culmine nonum forum cum thabernario (KDW I, 3). Rzecz istotna, że mamy tu do czynienia nie $\mathrm{z}$ dzisiejszym lokacyjnym Chełmnem, a jego piastowskim poprzednikiem - zespołem osadniczym, którego pozostałości odsłonięto $\mathrm{W}$ nieopodal położonym Kałdusie, na co wskazywali już dawniej niektórzy historycy (Nowak 1987, 65; Bieniak 1970, 11, $51-53,68)$ i archeolodzy (Kola 1975), a co zostało 


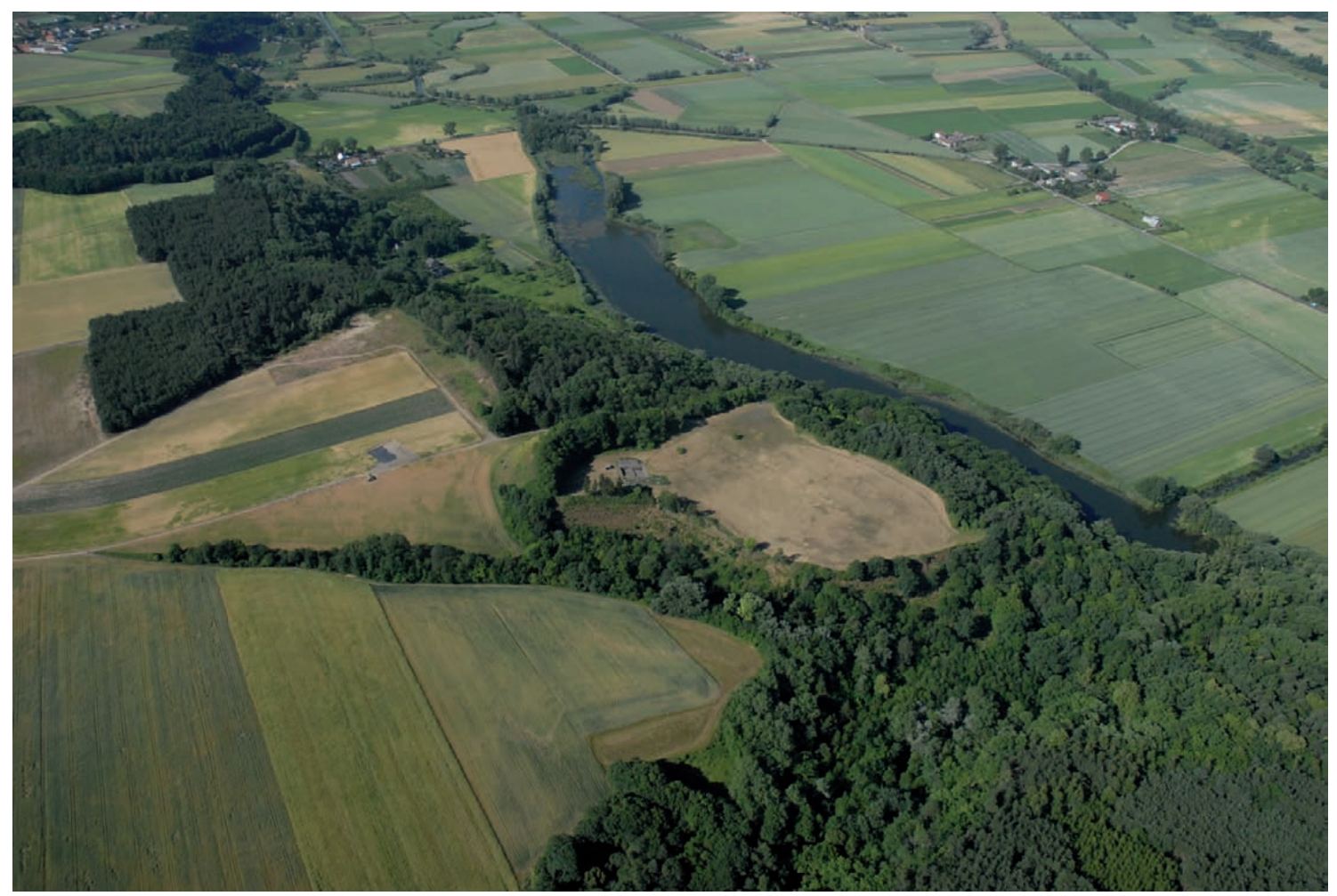

Ryc. 1. Góra św. Wawrzyńca w Kałdusie (woj. kujawsko-pomorskie), widok od wschodu. Fot. W. Stępień Fig. 1. Saint Laurentius Mountain in Kałdus (the Kuyavian-Pomeranian Voivodeship), view from the east. Photo by W. Stępień

dowodnie potwierdzone w trakcie dwóch ostatnich dekad badań (Chudziak 2010; Chudziak, Bojarski 2014; zob. ryc. 1).

Wspomniany kompleks osadniczy o całkowitej powierzchni około 12-14 hektarów zlokalizowany jest w północno-zachodniej części ziemi chełmińskiej, po prawobrzeżnej stronie Doliny Dolnej Wisły, na zachodnim skraju Wysoczyzny Chełmińskiej. Jego centralnym punktem jest dominująca nad otaczającym ją obszarem wysoczyzny morenowej i doliną Wisły Góra św. Wawrzyńca, która mogła pełnić rolę symbolicznego centrum wspólnoty lokalnej (imago mundi), idealnego w sensie fenomenologicznym punktu mediacyjnego między różnymi sferami działań ludzkich i sił sakralnych (axis mundi) (Chudziak 2003, 141 i n.; Szmańda, Lankauf, Luc 2004). W jego skład wchodzą grodzisko (stanowisko 3), położone na północ od Góry św. Wawrzyńca, osada podgrodowa (stanowisko 2), mieszcząca się na południowy wschód od wałów grodu oraz cztery odrębne, w sensie zajmowanej przestrzeni, nekropole zlokalizowane w obrębie trzech różnych stanowisk archeologicznych $-1,2$ i 4 (ryc. 2; zob. Chudziak 2003; Mons 2006; 2010; Bojarski, Chudziak, Weinkauf w druku b). Zain- teresowania archeologów tym kompleksem sięgają jeszcze XIX wieku, co związane było przede wszystkim z odkryciami dokonywanymi na cmentarzyskach (Drozd 2006, 13). Prace te kontynuowane były z różnym natężeniem przez cały XX wiek, jednak dopiero w latach 1996-2015 wczesnośredniowieczny kompleks osadniczy w Kałdusie poddany został systematycznym badaniom wykopaliskowym prowadzonym przez Instytut Archeologii UMK w Toruniu. Dzięki pozyskaniu odpowiedniego materiału źródłowego opracowano periodyzację rozwoju ceramiki naczyniowej tego ośrodka i zsynchronizowano z nią poszczególne etapy jego przestrzenno-funkcjonalnego rozwoju (fazy I-IX; Chudziak 2003).

Na podstawie dotychczasowych badań stwierdzono, że w XI-XII/XIII wieku bezpośrednio na północ od Góry św. Wawrzyńca znajdował się dwuczłonowy gród z gęstą miejscami zabudową wzniesioną w konstrukcji zrębowej (faza VI-IX). Zaś na południe od Góry, na jego przedpolu, usytuowana była osada podgrodowa, początkami sięgająca VIIVIII wieku (faza I), choć jej największe prosperity przypadło dopiero na 2. połowę XII i początek XIII wieku (faza IX), jak można wnioskować po dużej 


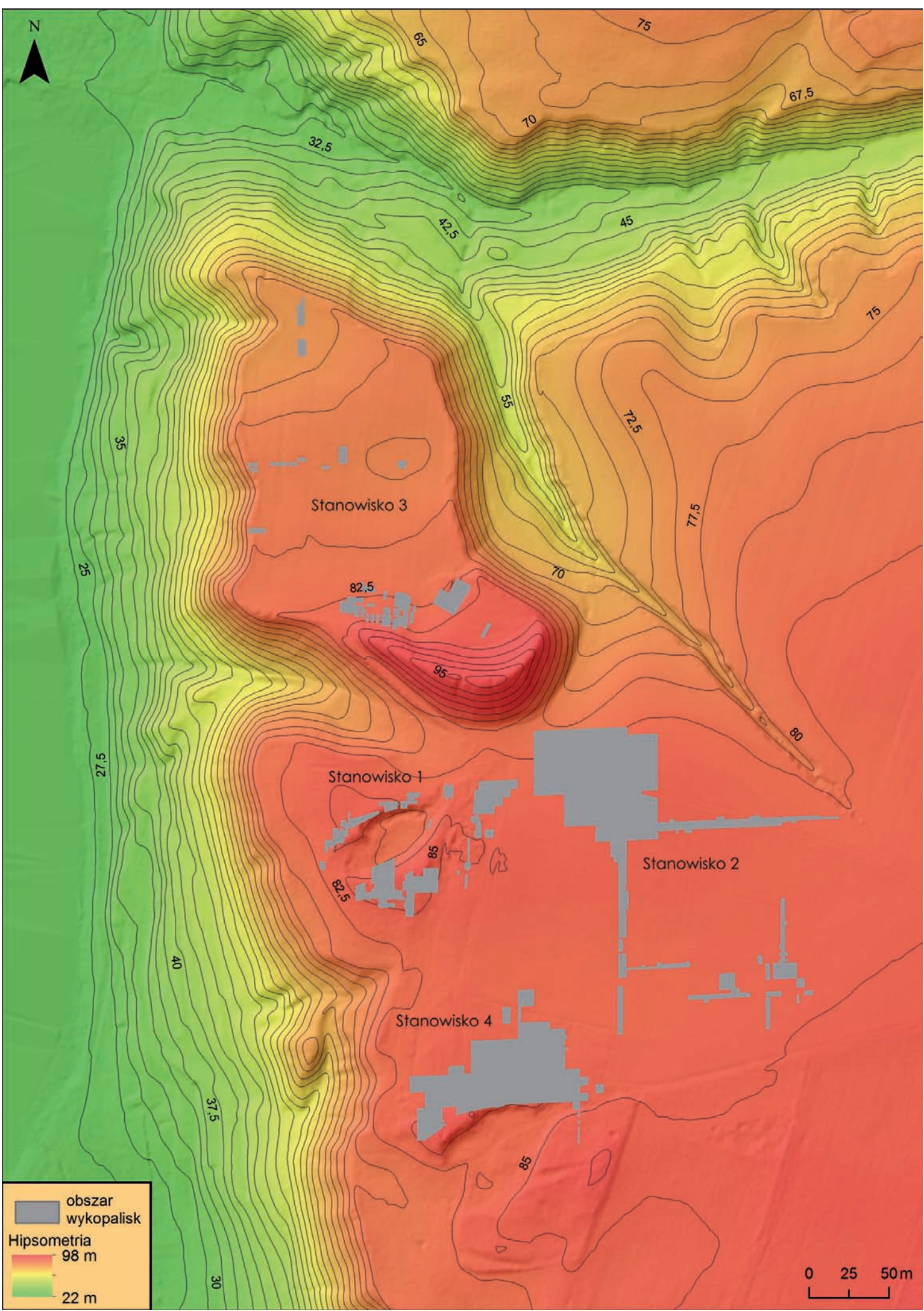

Ryc. 2. Kałdus, gm. Chełmno, woj. kujawsko-pomorskie. Plan sytuacyjno-wysokościowy wczesnośredniowiecznego zespołu osadniczego. Stanowisko 1: cmentarzysko i osada podgrodowa; Stanowisko 2: osada podgrodowa i cmentarzysko; Stanowisko 3: grodzisko; Stanowisko 4: cmentarzysko i osada podgrodowa. Rys. M. Skrzatek Fig. 2. Kałdus, Chełmno district, the Kuyavian-Pomeranian Voivodeship. The situational and altitude plan of the early medieval settlement complex. Site 1: burial ground and ancillary settlement; Site 2: ancillary settlement and burial ground; Site 3: fortified settlement; Site 4: burial ground and ancillary settlement. Drawn by M. Skrzatek 


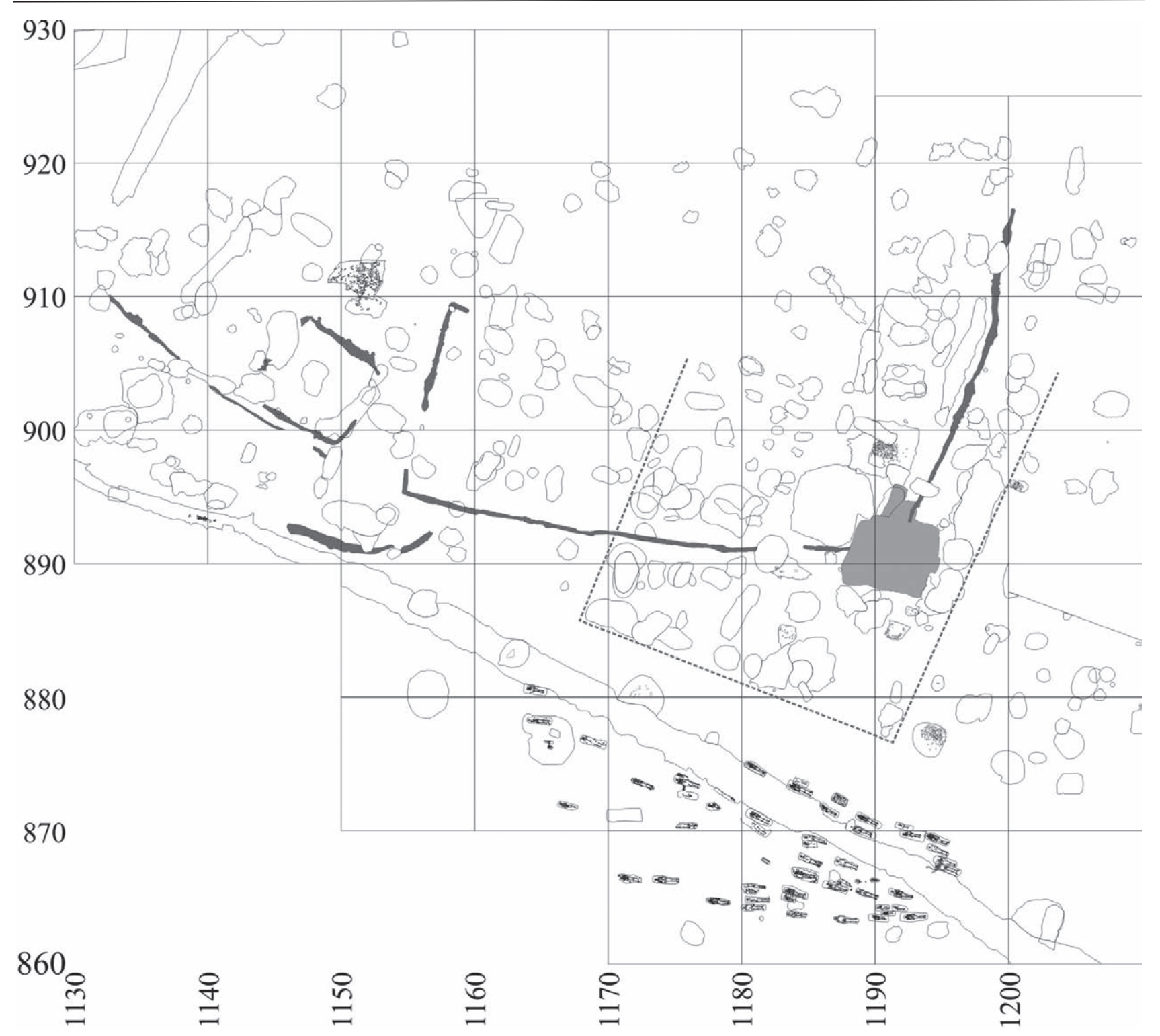

Ryc. 3. Kałdus, gm. Chełmno, woj. kujawsko-pomorskie, stanowisko 2. Planigrafia obiektów osadniczych wraz z lokalizacją domniemanej karczmy - obiekt 172, hipotetycznym zasięgiem związanej z nią zagrody oraz grobami z 2. połowy XI - 1. ćwierci XIII wieku (VII-IX faza zasiedlenia osady). Rys. M. Weinkauf

Fig. 3. Kałdus, Chełmno district, the Kuyavian-Pomeranian Voivodeship, site 2. Planigraphy of the settlement features with the location of the supposed inn - feature 172, hypothetical range of the farmstead connected with the inn and graves from the second half of the $11^{\text {th }}-$ the first quarter of the $13^{\text {th }}$ century (the $7^{\text {th }}-9^{\text {th }}$ phases of the settlement). Drawn by M. Weinkauf

liczbie obiektów osadniczych pochodzących z tego okresu (ryc. 3). Całkowita powierzchnia osady wynosiła wtedy około 2-3 hektary, z czego jak dotąd wyeksplorowano jedynie 64 ary, odsłaniając ponad 900 różnego rodzaju pod względem formy, wielkości i funkcji jam osadniczych ${ }^{5}$. Dla mieszkańców

\footnotetext{
5 Prace ratowniczo-wykopaliskowe w tej części kompleksu osadniczego zapoczątkowano w 1957 roku (Wiklak 1959a, 329; 1959b, 330-331; Matuszewska-Kola 1972, 95), ale szeroko zakrojone badania archeologiczne rozpoczęto
}

pobliskiego grodu była zarówno zapleczem gospodarczym, jak również ważnym ośrodkiem produkcji i wymiany, a jej rola zmieniała się wraz z rangą grodu będącego początkowo zapewne centrum administracyjnym i ideologicznym państwa pierwszych Piastów, tzw. sedes regni principalis, później

dopiero w 2002 roku (Weinkauf 2005; Bojarski, Chudziak, Weinkauf 2006; w druku b; Błędowski, Chudziak, Weinkauf 2007; Chudziak, Weinkauf 2009; Bojarski, Weinkauf 2011). 


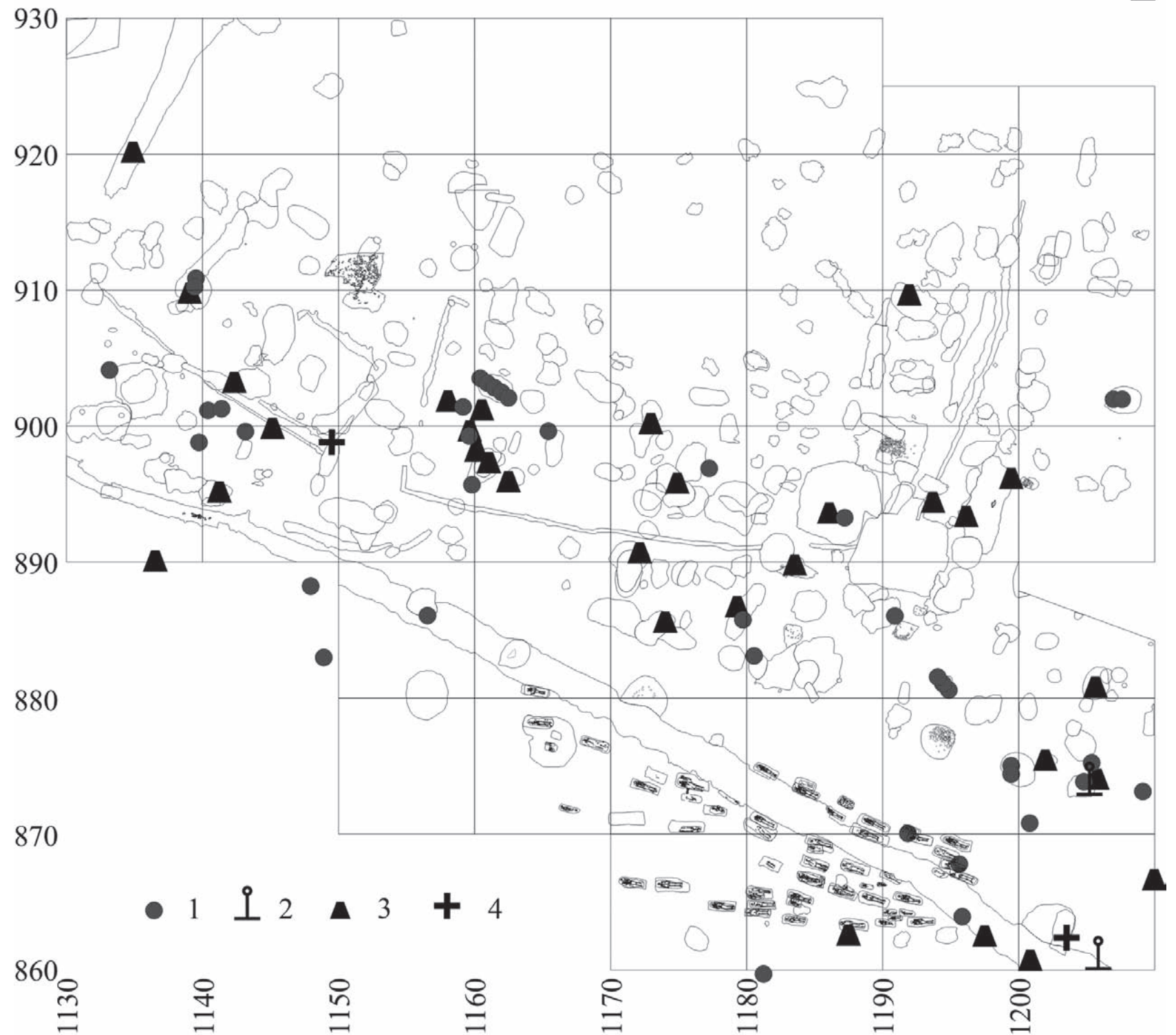

Ryc. 4. Kałdus, gm. Chełmno, woj. kujawsko-pomorskie, stanowisko 2. Planigrafia utensyliów kupieckich, monet oraz krzyżyków na tle obiektów osadniczych oraz grobów z 2. połowy XI - 1. ćwierci XIII wieku (VII-IX faza zasiedlenia osady). Legenda: 1 - moneta; 2 - waga; 3 - odważnik; 4 - krzyżyk. Rys. M. Weinkauf Fig. 4. Kałdus, Chełmno district, the Kuyavian-Pomeranian Voivodeship, site 2. Planigraphy of merchant utensils, coins and crosses with reference to settlement features and graves from the second half of the $11^{\text {th }}$ - the first quarter of the $13^{\text {th }}$ century (the $7^{\text {th }}-9^{\text {th }}$ phases of the settlement). Legend: 1 - a coin; 2 - scales; 3 - a weight; 4 -a cross.

Drawn by M. Weinkauf

zaś ośrodkiem rangi kasztelańskiej (2. połowa XI - 1. ćwierć XIII wieku; Chudziak 2003). Z tym etapem istnienia ośrodka in Culmine synchronizowana jest również większość grobów odsłoniętych na czterech cmentarzyskach, zawierających pochówki typowe dla eschatologii chrześcijańskiej. Liczba grobów z tego okresu wskazuje na znaczny wtedy potencjał demograficzny tego ośrodka (Kozłowski 2012).
Rozbudowany przestrzennie i wielofunkcyjny kompleks osadniczy położony u stóp Góry św. Wawrzyńca pełnił we wczesnym średniowieczu rolę ważnego węzła komunikacyjnego, usytuowanego na skrzyżowaniu szlaków dalekosiężnych prowadzących z Rusi na Pomorze i z głębi interioru zachodniosłowiańskiego w kierunku Bałtyku. Do tego zlokalizowany on był blisko pogranicza polsko-pruskiego i szlaku idącego z ziemi chełmińskiej 


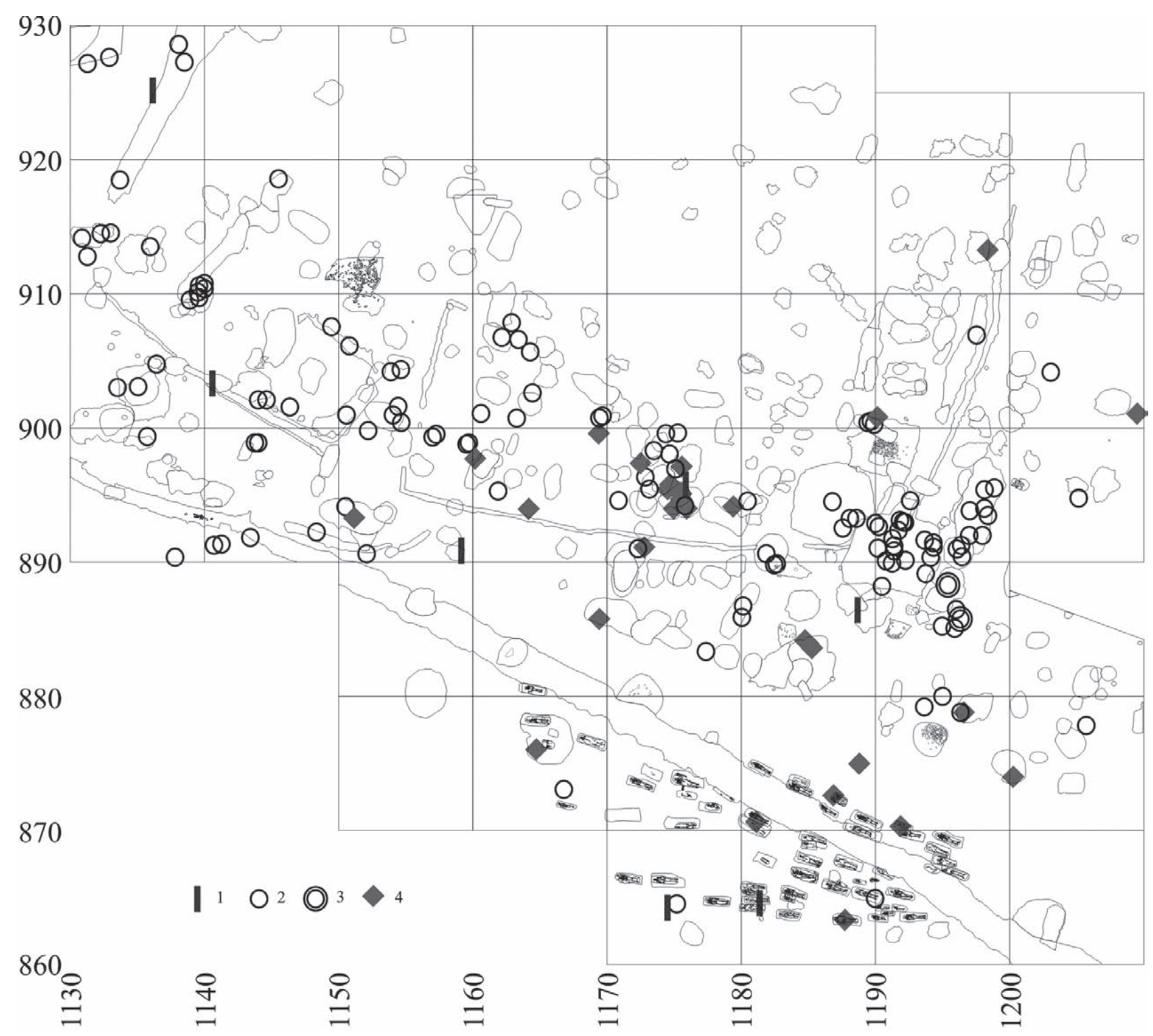

Ryc. 5. Kałdus, gm. Chełmno, woj. kujawsko-pomorskie, stanowisko 2. Planigrafia półproduktów i odpadów ze srebra, ołowiu, miedzi i żelaza na tle obiektów osadniczych oraz grobów z 2. połowy XI - 1. ćwierci XIII wieku

(VII-IX faza zasiedlenia osady). Legenda: 1 - półprodukty i odpady z żelaza; 2 - półprodukty i odpady ze srebra i ołowiu; 3 - półprodukty i odpady ze srebra i ołowiu $(\mathrm{N} \geq 8)$; 4 - półprodukty, odpady i przedmioty nieokreślone ze stopów miedzi. Rys. M. Weinkauf

Fig. 5. Kałdus, Chełmno district, the Kuyavian-Pomeranian Voivodeship, site 2. Planigraphy of silver, lead, copper and iron half-finished products and waste with reference to settlement features and graves from the second half of the $11^{\text {th }}$ - the first quarter of the $13^{\text {th }}$ century (the $7^{\text {th }}-9^{\text {th }}$ phases of the settlement). Legend: 1 - iron half-finished products and waste; 2 - silver and lead half-finished products and waste; 3 - silver and lead half-finished products and waste $(\mathrm{N} \geq 8) ; 4$ - copper alloy half-finished products, waste and undefined objects. Drawn by M. Weinkauf

w kierunku Prus. Miało to wszystko niewątpliwie wpływ na wiodącą rolę tego ośrodka $\mathrm{w}$ regionie i jego udział w lokalnej i ponadlokalnej wymianie handlowej, udokumentowanej w licznych źródłach archeologicznych. Jego strategiczne znaczenie jako centrum wymiany i wyspecjalizowanej produkcji potwierdzają liczne znaleziska, w tym przedmio- ty obcego pochodzenia (broń, ozdoby, naczynia), a przede wszystkim odkrywane wręcz masowo na terenie grodziska i osady podgrodowej utensylia kupieckie, reprezentowane przez monety (pojedyncze znaleziska i drobne depozyty zbiorowe), części wag szalkowych i różne rodzaje odważników, jak również liczne odpady produkcyjne (ryc. 4, 5). 
Świadczą one o rozwiniętej wielokierunkowej wymianie i kontaktach z najważniejszymi ośrodkami ówczesnej Europy, co nie powinno dziwić wobec pogranicznego - na styku Prus, Mazowsza, Kujaw i Pomorza - położenia ziemi chełmińskiej.

Najbardziej naturalny korytarz komunikacyjny stanowiła oczywiście Wisła (por. Bieniak 1970, 6-7, p. 4; Chudziak 1997). Równie ważne wydają się jednak połączenia lądowe - omawiany kompleks został zlokalizowany w największym przewężeniu doliny Wisły, w miejscu styku dwóch rozległych Basenów - Unisławskiego i Świeckiego. Zapewniło to dogodne warunki do powstania przeprawy wykorzystującej położone bezpośrednio przy zboczu doliny dawne koryto Wisły, dzisiejsze Jezioro Starogrodzkie i połączoną z nim i Wisłą rzeczkę Trynkę (Kordowski 2004). Dostęp do przeprawy ułatwiały drogi biegnace dolinkami erozyjnymi, które opasują z dwóch stron Górę św. Wawrzyńca i łączą się z dnem doliny. Podejrzewać należy, że z uwagi na łagodniejszy skłon wykorzystywano częściej, przynajmniej w odniesieniu do wozów, północną drogę.

Zarówno przystanie, jak i miejsca przepraw promowych, bo z taką mielibyśmy tu chyba do czynienia, są rzadko uchwytne archeologicznie (Filipowiak 2003; por. szerzej McGrail 1985), częściej na możliwość ich wykorzystywania wskazują uwarunkowania przyrodnicze i osadnicze (por. szerzej Augustyniak 2014). O istnieniu przewozu w pobliżu Góry św. Wawrzyńca tzw. falsyfikat mogileński milczy, choć można domyślać się go w grupie niewymienionych z nazwy, wzmiankowanych w tym samym dokumencie, przewozów na Wiśle wystę- pujących od Kamienia do morza, niezależnie o którym Kamieniu myślimy (transitus omnes per Vyslam de Camen usque ad mare) (Labuda 1978, 27-38; por. szerzej Powierski 1996, 148-157). Wiadomo wszakże, iż prawo do przewozu posiadał zazwyczaj panujący, który w czasie wprowadzania prawa niemieckiego mógł przenieść je na miasta (Dąbkowski 1914, 268). Wówczas dopiero przekazanie regale (lub też karczma, por. wyżej) mogło znaleźć się po raz pierwszy w źródłach pisanych, jak to wykazał na przykładzie wschodniopomorskiego regale targowego Tadeusz Lalik (1965). Wydaje się zatem, że pomimo nawet dyskusyjnej kwestii translokacji Chełmna (por. Jóźwiak 1996), swobodny przewóz (navigium liberum) przez Wisłę nadany temu miastu w jego przywileju lokacyjnym w 1233 r. (PUB, nr 105), później potwierdzonym w 1247 r. (PomUB, nr 96), utożsamiać można z przeprawą usytuowana w pobliżu Kałdusa.

W tym kontekście wczesnośredniowieczny zespół osadniczy w Kałdusie, czyli pierwotne Chełmno, zwłaszcza w młodszych fazach jego funkcjonowania uznać należy za gateway city, bramę do ziemi chełmińskiej. Nie wyklucza to też i innych ważnych funkcji przezeń pełnionych i tym samym traktowania go jako multifunkcyjny ośrodek centralny (central place) (Burghardt 1971, 282, 284; Krzysztofik 2004, 221; por. też Siemianowska 2014, 35-39, tam dalsza literatura). Wymieniona w źródłach karczma in Culmine, przypadająca na okres wymiany lokalnej i rozwoju targów, koresponduje zatem z rangą omawianego ośrodka, której siedziby upatruje się w grodzie przy Górze św. Wawrzyńca (Bieniak 1970, 50-53).

\section{OBIEKT 172 - STRUKTURA, STRASTYGRAFIA KULTUROWA I PRÓBA REKONSTRUKCJI}

W północno-zachodniej partii osady podgrodowej (stanowisko 2), w miejscu największego wypiętrzenia terenowego, około 70-80 metrów na wschód od podstawy Góry św. Wawrzyńca i około 100 metrów od domniemanej bramy wjazdowej do grodu, natrafiono na obiekt oznaczony numerem 172, związany z najmłodszym etapem rozwoju osady podgrodowej, przypadającym 2 . połowę XII i 1. ćwierć XIII wieku'. Określenie jego chronologii możliwe było na podstawie analizy układu

${ }^{6}$ Badania prowadzono w 2004 roku w ramach grantu KBN nr H01H 05227 pt. Wczesnośredniowieczny zespół stratygraficznego oraz ruchomego materiału źródłowego, a zwłaszcza zbioru naczyń ceramicznych pod względem technologiczno-stylistycznym ściśle nawiązującego do najmłodszego horyzontu rozwojowego lokalnego garncarstwa (faza IX; Chudziak 2003, 19-25). Z omawianą serią naczyń zsynchronizowano wiele innych zespołów ceramicznych z tego stanowiska, co ważne współwystępujących ze znaleziskami monetarnymi, m.in. denarami Władysława II z lat 1144-1146 (obiekt 327), Bolesła-

osadniczy w Kałdusie - chetmiński sedes regni principales (projekt 2). 


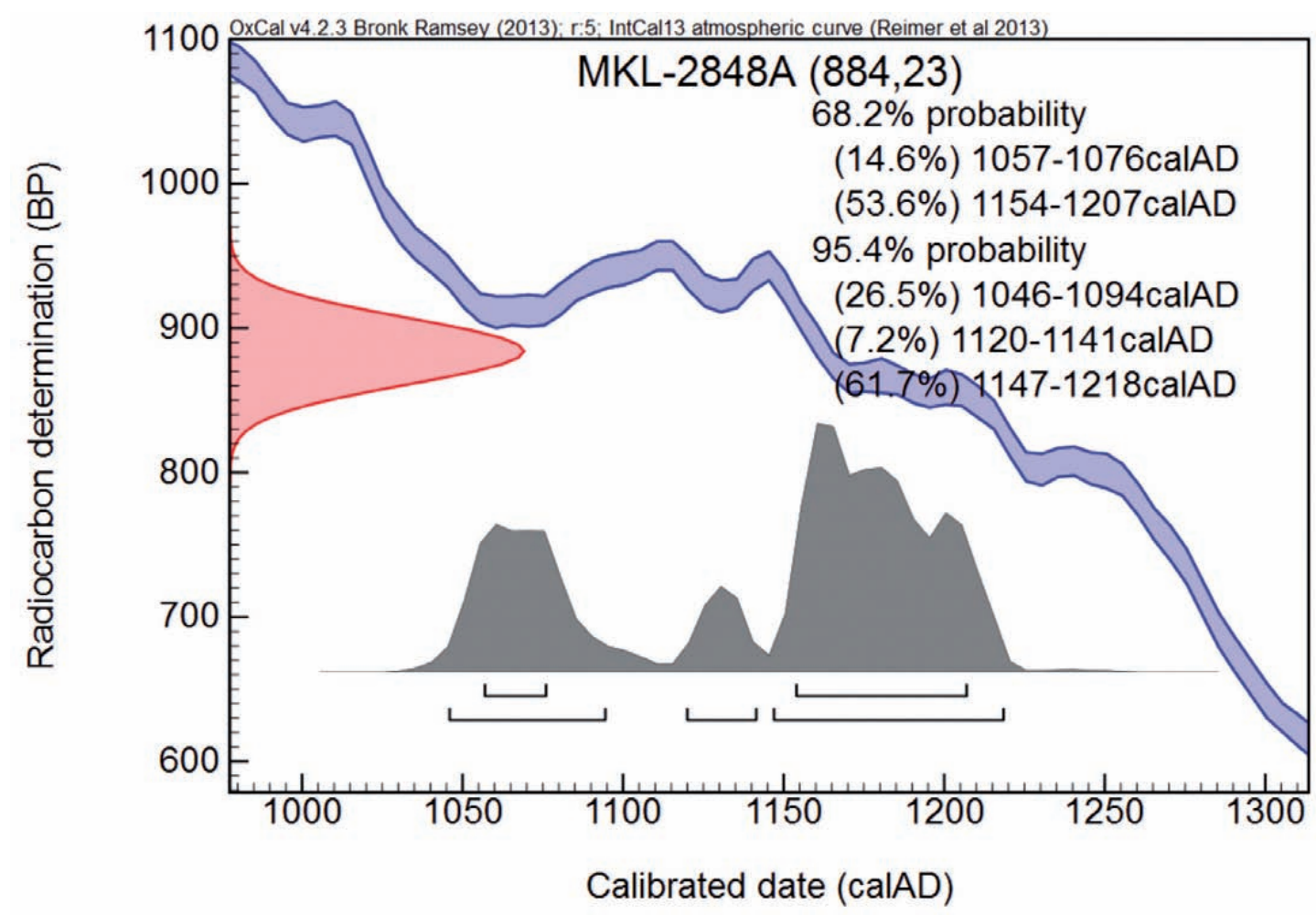

Ryc. 6. Kałdus, gm. Chełmno, woj. kujawsko-pomorskie, stanowisko 2. Wykres kalibracji próbki MKL-2848A (182/2004) pochodzącej z obiektu 172, warstwa LXXIV. Wg M. Krapca

Fig. 6. Kałdus, Chełmno district, the Kuyavian-Pomeranian Voivodeship, site 2. Calibration chart of the sample MKL-2848A (182/2004) from the feature 172, layer LXXIV. After M. Krapiec

wa Kędzierzawego z lat 1146-1173 (obiekty 351, 1030), Kazimierza Sprawiedliwego z lat 1185-1194 (obiekt 1080) oraz brakteatami z przełomu XII/XIII i 1. połowy XIII wieku (obiekt 538).

Przyporządkowanie obiektu 172 do tego etapu rozwoju osady potwierdziły również wyniki analiz ${ }^{14} \mathrm{C}$ wykonane w laboratorium w Cianowicach przez prof. dr hab. Marka Krapca (MKL-2848A) wskazujące, że zwęglona materia pochodząca $\mathrm{z}$ drewnianej konstrukcji karczmy mieści się z prawdopodobieństwem $61,7 \% \mathrm{w}$ przedziale $1147-1218$ AD $(884 \pm 23$ BP) (ryc. 6).

Eksplorację obiektu, ze względu na jego znaczne rozmiary, prowadzono w obrębie sześciu oddzielnych działek badawczych (A-F). W jej efekcie odsłonięto pozostałości budynku w rzucie względnie regularnie czworokątnego, częściowo zagłębionego w ziemię, wyróżniającego się ponadnormatywnymi rozmiarami spośród tego rodzaju obiektów odkrytych dotąd na osadzie (ryc. 7). Wypełnisko obiektu 172 tworzyło 83 jednostek stratygraficznych, z reguły nieckowato zalegających warstw ciagłych lub ich soczewek. Na podstawie analizy jego struktury wyróżniono cztery warstwy zasadnicze, związane z głównymi etapami zachodzących procesów depozycyjnych: a) warstwę demolacyjno-rumowiskową w postaci ciemnobrunatno-szarożółtego piasku gliniastego zawierającego domieszkę spalenizny i polepy, zdeponowana po zniszczeniu obiektu i jego przejściu w kontekst stratygraficzny (warstwa I); b) dwie zalegające horyzontalnie warstwy ciemnoszarej próchnicy ze spalenizną stanowiące relikty dwóch poziomów drewnianych podłóg (poziom I i III - warstwa XXXIII i LXXIV) oraz c) warstwa jasnożółtej gliny rozdzielającej oba poziomy podłóg (gliniane klepisko, poziom II - warstwa XLVI) (ryc. 8). Pozostałe wyróżnione jednostki stratygraficzne, z reguły niewielkie soczewki warstw, koncentrowały się na obrzeżach obiektu i stanowiły pozostałość konstrukcji drewnianych. Na uwage zasługuje natomiast warstwa popiołu odkryta w centralnej części obiektu - warstwa XXXII (ryc. 7-8).

Stosunkowo dobrze zachował się pierwotny kształt budynku, co pozwala na wnioskowanie dotyczące jego wielkości. Wymiary negatywów ścian mierzonych po linii W-E wynosiły $6,7 \mathrm{~m}$, a po osi $\mathrm{N}-\mathrm{S}-5,5 \mathrm{~m}$, a wliczając w to pozostałości korytarza wejściowego stwierdzonego od strony północnej, 


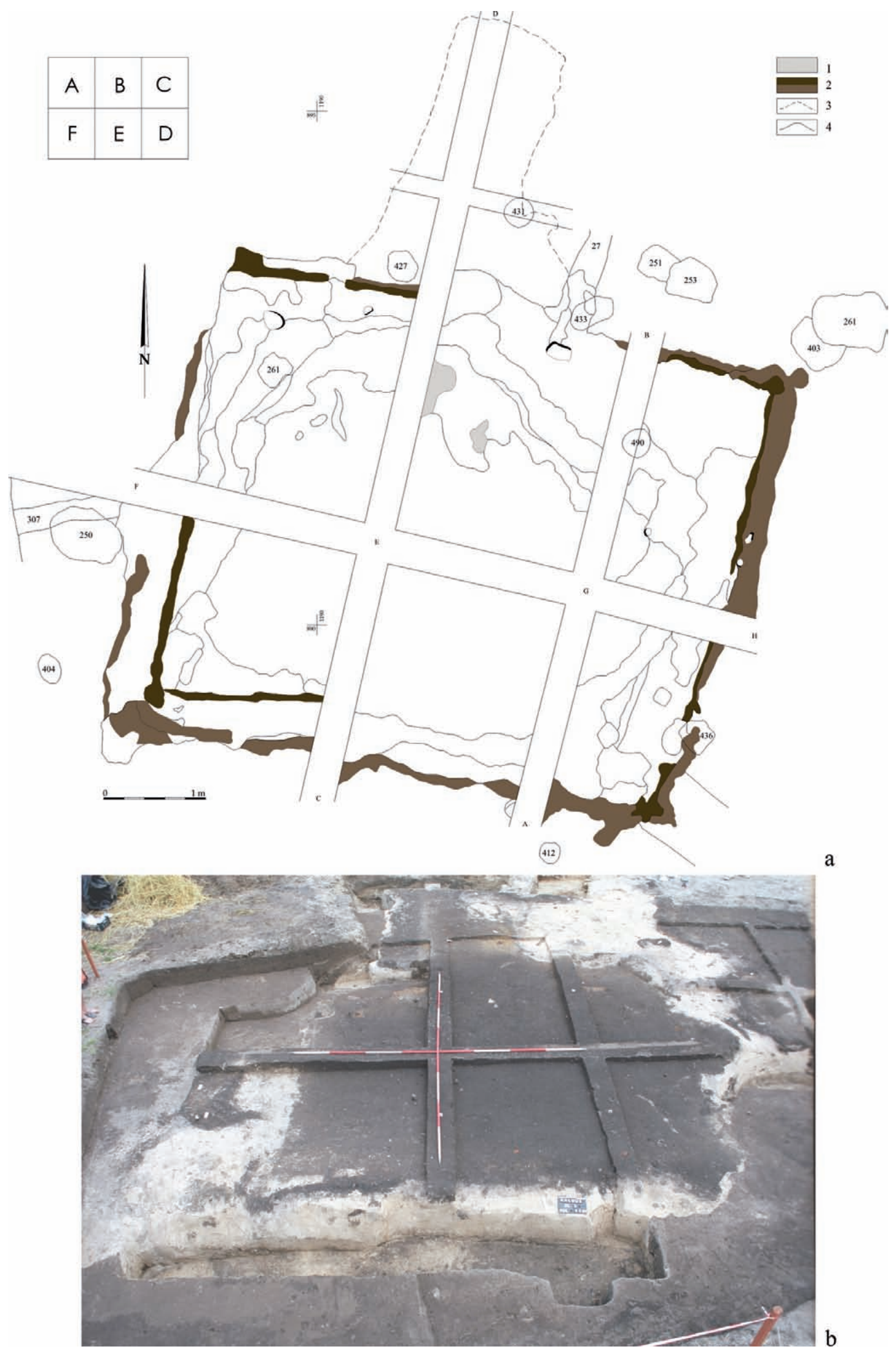

Ryc. 7. Kałdus, gm. Chełmno, woj. kujawsko-pomorskie, stanowisko 2. Domniemana karczma (obiekt 172). Rzut poziomy: a - I i IV poziom eksploracji wraz z wejściem i negatywami posłupowymi; b - I poziom eksploracji, widok od południa. Legenda: 1 - warstwa popiołu; 2 - elementy drewnianej konstrukcji budynku; 3 - I poziom eksploracji; 4 - IV poziom eksploracji. Opr. P. Szczepanik, M. Weinkauf; fot. P. Biarda

Fig. 7. Kałdus, Chełmno district, the Kuyavian-Pomeranian Voivodeship, site 2. The supposed inn (feature 172). Horizontal projection: $\mathrm{a}-\mathrm{I}$ and IV level of exploration with the entrance and post-hole impressions; $\mathrm{b}$ - I level of exploration, view from the south. Legend: 1 - ash stratum; 2 - elements of wooden building construction; 3 - the 1st level of exploration; 4 - the 4th level of exploration. Elaborated by P. Szczepanik, M. Weinkauf; photo by P. Biarda 
DOMNIEMANA KARCZMA WCZESNOŚREDNIOWIECZNA W KAŁDUSIE
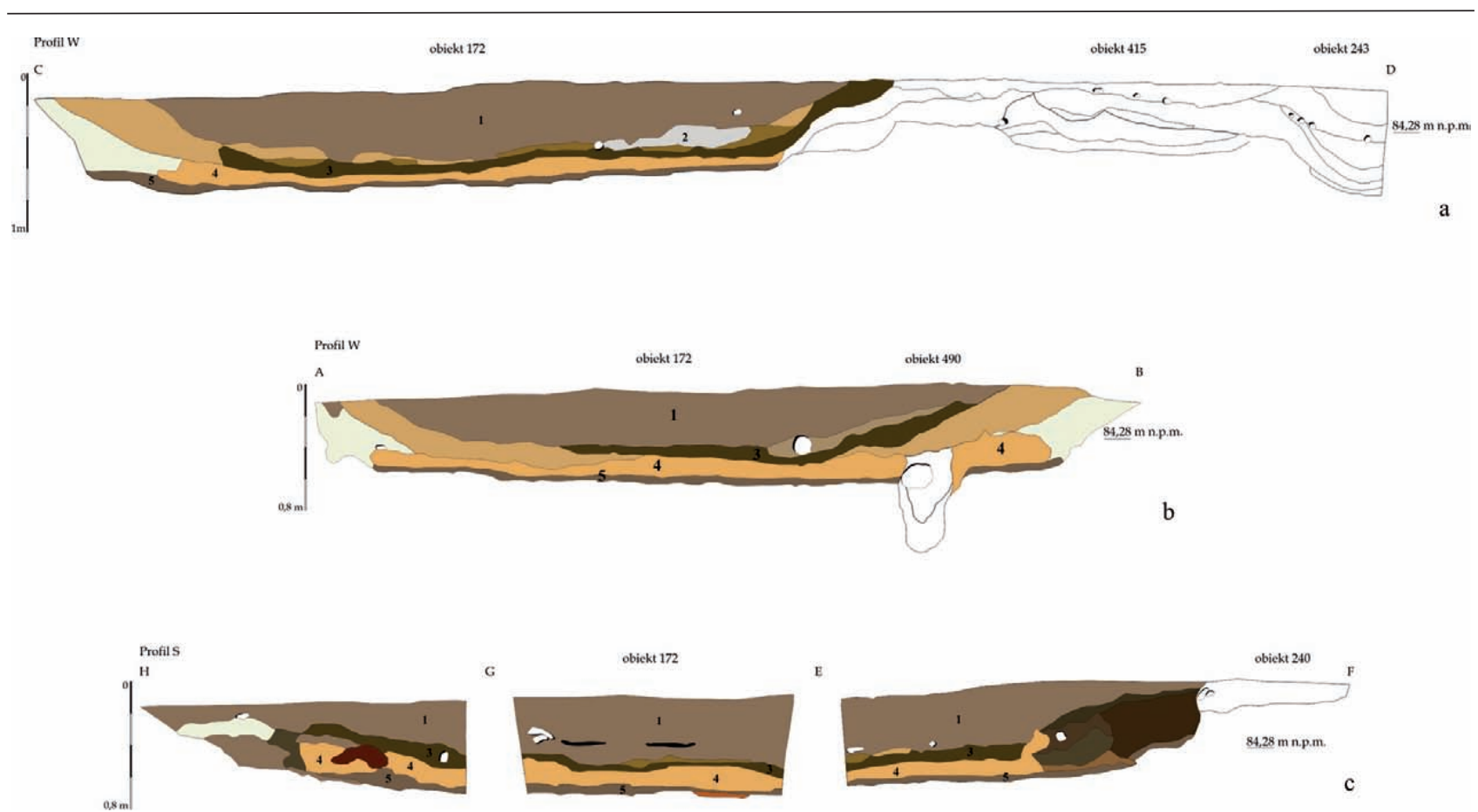

Ryc. 8. Kałdus, gm. Chełmno, woj. kujawsko-pomorskie, stanowisko 2. Domniemana karczma (obiekt 172). Legenda: a-b - profil W; c - profil S. Opis wybranych warstw: 1 - warstwa I: ciemnobrunatno-szarożółty piasek gliniasty ze spalenizną i polepą; 2 - warstwa XXXII: pomarańczowo-żółto-szary piasek gliniasty z popiołem; 3 - warstwa XXXIII: szaro-ciemnobrunatno-żółty piasek gliniasty ze spalenizną; 4 - warstwa XLVI: żółto-pomarańczowo-ciemnobrunatny piasek gliniasty z polepą; 5 - warstwa LXXIV: brązowo-szary piasek gliniasty ze spalenizną. Opr. P. Szczepanik, M. Weinkauf

Fig. 8. Kałdus, Chełmno district, the Kuyavian-Pomeranian Voivodeship, site 2. The supposed inn (feature 172). Legend: $\mathrm{a}-\mathrm{b}$ - cut W; $\mathrm{c}$ - cut S. Description of selected layers: 1 - layer I: dark brownish-gray-yellow clayish sand with burnt particles and pug; 2 - layer XXXII: orange-yellow-gray clayish sand with ashes; 3 - layer XXXIII: graydark brown-yellow clayish sand with burnt particles; 4 - layer XLVI: yellow-orange-dark brown clayish sand with pug; 5 - layer LXXIV: brownish-gray clayish sand with burnt particles. Elaborated by P. Szczepanik, M. Weinkauf

szerokość całej konstrukcji sięgała 7,9 m. Całkowita powierzchnia obiektu wynosiła około $37 \mathrm{~m}^{2}$, a razem z korytarzem $40 \mathrm{~m}^{2}$. Dobrze czytelne pozostałości detali architektonicznych w postaci jam posłupowych oraz poziomych smug próchnicznego piasku - śladów po zbutwiałym drewnie - pozwalają na wnioskowanie co do pierwotnej konstrukcji budynku (ryc. 9). Zarejestrowane w trzech narożnikach negatywy słupów oraz tworzące regularny czworokąt relikty ścian świadczą o tym, że budynek ten został wzniesiony prawdopodobnie w technice sumikowo-łątkowej. Ślady po pionowych słupach narożnych (łątkach) to zazwyczaj jedyny czytelny ślad obiektów wznoszonych w tejże technice, poziome elementy (sumiki), wpuszczane w tzw. pazy (czyli wyżłobienia w łątkach), bardzo rzadko zagłębione w ziemię, równie rzadko zachowują się. W obrębie obiektu nie stwierdzono obecności negatywów słupów pośrednich pozwalających na zastosowanie krótszego budulca jako sumików oraz tym samym uzyskanie budynku o zdecydowanie większych rozmiarach (por. Kostrzewski 1962, 104). Brak ten może być wynikiem wykorzystania surowca o długości odpowiadającej wymiarom planowanych ścian bądź też zastosowania podwaliny w formie drewnianej ramy (przyciesi), w której umieszczono pośrednie łątki, nie zostawiających śladów w gruncie (por. np. Karpińska 1935, 5).

Od północnej strony budynku zadokumentowano ślady sporych rozmiarów wejścia (wymiary: $2,10 \times 2,50 \mathrm{~m}$ ) oraz zadaszenia (podcienia) w postaci trzech negatywów jam posłupowych, występujących wzdłuż całej ściany budynku, oddalonych od niej około 1 metra. Wejście z podcieniem umiejscowione było od strony naturalnego stoku, wzdłuż podnóża, którym przebiegała prowadząca $\mathrm{z}$ doliny Wisły do grodu droga. Samo wejście do budynku miało regularny prostokątny kształt, a jego poziom 

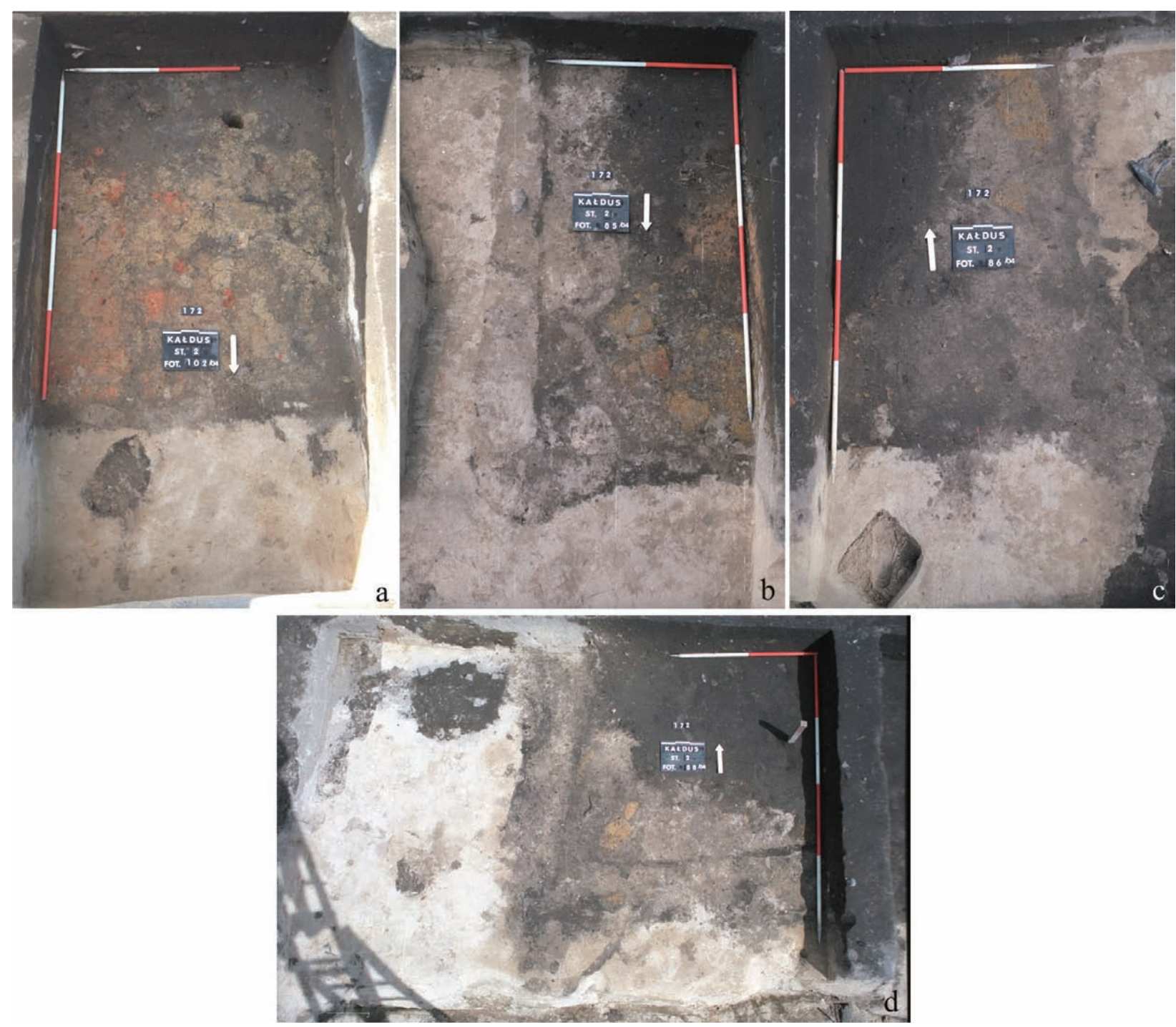

Ryc. 9. Kałdus, gm. Chełmno, woj. kujawsko-pomorskie, stanowisko 2. Domniemana karczma - (obiekt 172, III poziom eksploracji). Elementy konstrukcyjne budynku: a - część B, widok od N; b - część C, widok od N; c - część D, widok od S; d - część F, widok od S. Fot. P. Biarda

Fig. 9. Kałdus, Chełmno district, the Kuyavian-Pomeranian Voivodeship, site 2. The supposed inn (feature 172 , III level of exploration). Structural elements of the building: $a$ - part B, view from the north; $b$ - part $C$, view from the north; $\mathrm{c}$ - part D, view from the south; $\mathrm{d}$ - part F, view from the south. Photo by P. Biarda

zagłębienia w gruncie był płytszy od właściwej części budynku. Prawdopodobnie różnica poziomów została zniwelowana przez zastosowanie bliżej nieokreślonej formy schodów, po których wchodziło się do środka. Wnętrze budynku odznacza się dwoma poziomami użytkowania, związanymi być może z wymianą podłogi. W pobliżu południowozachodniego narożnika natrafiono na pozostałości drewnianej konstrukcji, będącej śladem po znajdującej się być może w tym miejscu narożnej ławie. Prawdopodobnie wykonana była tak jak cały budynek, w konstrukcji sumikowo-łątkowej, umocowanej do ściany lub mającej formę skrzyni (zachował się jeden dobrze czytelny negatyw słupa oraz równoległe do ścian smugi zbutwiałego drewna).

W obiekcie nie zaobserwowano śladów po jakimkolwiek urządzeniu grzewczym, podstawowym wyznaczniku funkcji mieszkalnej odkrywanych obiektów. Brak również danych wskazujących na dwukondygnacyjną formę budynku, w którym palenisko znajdowałoby się na piętrze - tego typu konstrukcje znane są przede wszystkim z terenów północnej Rusi (Hensel 1987, 524; Barnycz-Gupieniec 2014, 91-92); Józef Kaźmierczyk opowiadał się za piętrowym charakterem budynku odkrytego na Ostrowie Tumskim we Wrocławiu, co miało stano- 
wić według niego argument przemawiający za jego funkcją jako karczmy (Kaźmierczyk 1993, 127).

Podobnie brak wiarygodnych przesłanek do rekonstrukcji wyglądu ewentualnego poddasza, jak również dachu. W centralnej części budynku, w niewielkiej odległości od wejścia, odkryto występującą na niewielkiej przestrzeni wspomnianą wcześniej warstwę popiołu, która może być dowodem korzystania w celach grzewczych, jak i oświetleniowych z przenośnego źródła ognia, podwieszonego nad podłogą lub innej podobnej konstrukcji. Naturalnie nie można odrzucić możliwości użytkowania paleniska czy też pieca na zewnątrz budynku, służącego do przygotowywania potraw, jak to się nieraz spotyka na innych wczesnośredniowiecznych osadach (Dąbrowska 1971, 371).

W świetle wyników dotychczasowych studiów nad wczesnośredniowiecznym budownictwem drewnianym Słowiańszczyzny stwierdzić należy, że technikę sumikowo-łątkową niezwykle rzadko wykorzystywano do wznoszenia budynków mieszkalnych. Częściej stosowano ją do stawiania różnego rodzaju dobudówek lub niewielkich pomieszczeń gospodarczych. Z obszaru nadbałtyckiego znanych jest zaledwie kilka dobrze rozpoznanych stanowisk, takich jak Gdańsk, Szczecin, Pułtusk, a także Ryga, Haithabu czy Stellerburg, gdzie stwierdzono występowanie budynków o podobnej konstrukcji (Barnycz-Gupieniec 2000, 115-116). Budynki te nie dorównywały jednak wielkością obiektowi z Kałdusa, również ich funkcja wydaje się być nie do końca jasna. Wyjątkiem w tym przypadku może być budynek odkryty na terenie wczesnośredniowiecznego Wolina, wzniesiony z przepołowionych belek dębowych prawdopodobnie w technice sumikowo-łątkowej. Jednak jego funkcję połączono ze sferą religijną (Filipowiak 1993, 26-27; Stanisławski 2011, 238-239).

O wiele więcej wspólnego obiekt z Kałdusa zdaje się mieć z reliktami budynków odkrytych jeszcze w okresie międzywojennym na osadach wczesnośredniowiecznych w Poznaniu-Sołaczu (pow. loco) z końca X i początku XI wieku, Dobczynie (pow. śremski) z VI-VII wieku oraz Zgniłce (pow. sępoleński) z IX-XI wieku (Karpińska 1935; Naumowiczówna 1961; Kostrzewski 1962, 103-104). Przy ich wznoszeniu zastosowano najprawdopodobniej technikę sumikowo-łątkową bądź też, tak jak przypuszczalnie w Sołaczu, technikę plecionkową. Umożliwiało to uzyskanie większych wymiarów budowli: w Sołaczu długość ścian wynosiła od 6,90 do $8,30 \mathrm{~m}$, szerokość zaś 5,20 do $6,50 \mathrm{~m}$, w Dobczynie wymiary ścian mierzyły odpowiednio 3,40 x 8,70 m, natomiast w Zgniłce $6,20 \times 13,75 \mathrm{~m}$. W Sołaczu przebadano cztery takie chaty, w Zgniłce - dwie; dodatkowo posiadały one otwarte podcienia słupowe, a wejścia w obu przypadkach znajdowały się od strony ulicy; w podobne podcienia zaopatrzono też budynki odsłonięte w Dobczynie. W ich obrębie, inaczej niż w obiekcie z Kałdusa, znajdowały się paleniska, a wnętrza ich były podzielone na dwie mniejsze części (Karpińska 1935; Naumowiczówna 1961; Kostrzewski 1962, 103-104). Ten ostatni argument według Piotra Boronia wyklucza możliwość zaliczenia ich do dużych budynków halowych, choć, jak sam zaznacza, pewne uzasadnione wątpliwości w tym zakresie budzić może chata II ze Zgniłki, gdzie podziału przestrzeni nie zaobserwowano ${ }^{7}$.

Poza powyższymi przykładami relikty podcieni zidentyfikowano również we wzmiankowanych już wcześniej budynkach odsłoniętych na podgrodziu na poznańskim Ostrowie Tumskim, a także na podgrodziu na warszawskim Bródnie, gdzie stwierdzono występowanie podcieni wypustowych. W przeciwieństwie do budynku z Kałdusa obie te budowle wzniesiono jednak w technice zrębowej. Chronologię pierwszej określono na $X$ wiek, drugiej zaś na X-XI stulecia, jakkolwiek Marek Dulinicz skłonny był chronologię tego ostatniego przesuwać nawet na IX wiek (Hensel 1958, 151; Musianowicz 1950; Dulinicz 1987, 124-125, 129). Warto w tym miejscu przypomnieć o unikalnym znalezisku koła szprychowego w tejże chacie z Bródna (Musianowicz 1950), położonego - jak sama nazwa wskazuje - nad brodem, który stał się zaczątkiem warszawskiego węzła komunikacyjnego (por. DuninWąsowicz 1975). Natomiast w reliktach budynku zrębowego zinterpretowanego jako karczma, a odkrytego na wrocławskim Ostrowie Tumskim znaleziono część osi wozu dwukołowego, ale nie powiązano jej w żaden sposób z domniemaną funkcją tego obiektu (Kaźmierczyk 1993, 127).

7 Poważne zastrzeżenia co do słuszności przeprowadzonej interpretacji budzi zwłaszcza to, że publikacji wyników badań na tym stanowisku po wielu latach podjęła się osoba nie uczestnicząca osobiście w pracach terenowych, a dodatkowe trudności interpretacyjne wynikały z dużego zagęszczenia różnego rodzaju jam kulturowych (Boroń 1997, 31). 


\section{OBIEKT 172 - ANALIZA RUCHOMEGO MATERIAŁU ŹRÓDŁOWEGO}

Istotnych informacji na temat funkcji obiektu 172 dostarczają liczne źródła ruchome pozyskane z jego wypełniska, zarówno stricte archeologiczne, jak i archeozoologiczne oraz archeobotaniczne, wszystkie zinwentaryzowane $\mathrm{w}$ ramach wyodrębnionych działek badawczych (A-F).

Naczynia ceramiczne. $Z$ omawianego obiektu pochodzi 2778 fragmentów ceramiki, w tym 2204 brzuśce, 368 wylewów, 206 den (ryc. 10, tab. 1). Częściowa rekonstrukcja form naczyń była możliwa w przypadku 224 większych ich partii, co umożliwiło przyporządkowanie analizowanych naczyń do konkretnych grup technologiczno-morfologicznych, a w konsekwencji do określonej fazy rozwoju lokalnej wytwórczości garncarskiej. Dominująca grupe stanowi 2764 fragmenty naczyń całkowicie obtaczanych $(99,5 \%$ całego zbioru), które reprezentują nurt garncarstwa z końca XII i pierwszej połowy XIII wieku, a reszta $0,5 \%$ to 14 fragmentów naczyń ręcznie lepionych i częściowo obtaczanych. Większość ułamków ceramiki została pozyskana z warstwy I (2208 fragmentów - 79,5\% całego zespołu), zalegającej w partii stropowej wypełniska obiektu. Naczynia te charakteryzują się bardzo wysokim standardem wykonania. Są to egzemplarze cienkościenne z wyodrębnioną szyjką, o baniastych i esowatych profilach, które zaopatrzono $\mathrm{w}$ silnie wywinięte na zewnątrz wylewy, $\mathrm{z}$ wrębem na pokrywkę i okapem. Do ich wykonania użyto średniotłustej, dobrze wyrobionej masy garncarskiej zawierającej dużą ilość, równo rozprowadzonej, starannie wysortowanej domieszki schudzającej, w postaci drobnego tłucznia z dodatkiem piasku. Górne oraz środkowe partie naczyń ozdobiono za pomocą dookolnych równych żłobków, dodatkowo uzupełnionych (w zwieńczeniu) liniami falistymi wykonanymi rylcem i pasami nakłuć lub nacięć. Dna formowano na podkładce centrującej, zaopatrując część z nich w znaki garncarskie, najczęściej w postaci prostego, równoramiennego krzyża. Naczynia wypalono w atmosferze utleniającej, ewentualnie neutralnej, w wysokiej temperaturze, co pozwalało uzyskać wyroby o twardej powierzchni. Wśród zrekonstruowanych form obecne były proste naczynia doniczkowate (stożkowata dolna partia brzuśca, 35 egzemplarzy) oraz duże garnki zasobowe z doklejanymi listwami dekorowanymi pasmami nakłuć (15 egzemplarzy) (ryc. 11). Odmienne cechy technologiczno-stylistyczne zaobserwowano $\mathrm{w}$ materiale ceramicznym pochodzącym ze spagowych partii obiektu (warstwy XXX, XXXVII, XLVI). Wystąpiły tu formy grubościenne o esowatych i baniastych profilach, bez szyjki oraz egzemplarze z cylindryczną szyjką. Wykonano je $z$ tłustej gliny schudzonej średnim i grubym tłuczniem. Mniej starannie wykonano również zdobienia w postaci głębokich żłobków oraz odcisków stempla. Naczynia te wypalono w atmosferze neutralnej.

Przedmioty wydzielone. Równie ważne dla określenia przeznaczenia obiektu 172 są odkryte w jego obrębie przedmioty, pełniące pierwotnie różnorakie funkcje (ryc. 12). Na zbiór liczący 55 egzemplarzy składają się głównie narzędzia, odpady produkcyjne i ozdoby. Liczny zespół (13 egzemplarzy) reprezentują przedmioty związane z codziennymi czynnościami domowymi. Najpowszechniejsze w tej grupie narzędzi noże żelazne reprezentowane są przez sześć egzemplarzy. Wyjątkowy okaz przedstawia nóż wykonany w technice dziwerowania (ryc. 13: c), którego głownia po obu stronach tylca ma zdobienia $\mathrm{w}$ formie ukośnych kresek podkreślonych poziomą linią (typ IIb; Rogosz 1983, 264-265). Dwa egzemplarze tej odmiany znane są z pobliskiego cmentarzyska (stanowisko 1), oba jednak niezdobione (Weinkauf 2006, 89). Na obecnym etapie badań trudno stwierdzić, czy tak zaawansowany proces obróbki metalu, połączony ze zdobieniem powierzchni inkrustacją, mógł mieć miejsce w lokalnych warsztatach rzemieślniczych. Nie jest wykluczone, że nóż ten trafił na teren osady wraz z innymi przedmiotami na drodze wymiany handlowej. Co prawda, liczne żelazne odpady poprodukcyjne odkrywane na tym stanowisku niewątpliwie dowodzą miejscowej obróbki kowalskiej, nie znamy jednak stopnia jej zaawansowania technologicznego. Niemniej jednak, nóż wykonany w technice dziwerowania (damastu skuwanego) należy do relatywnie rzadkich znalezisk, gdyż taki sposób obróbki żelaza we wczesnym średniowieczu stosowano przeważnie do produkcji głowni mieczy lub grotów włóczni (Piaskowski 1974; Kucypera 2009).

Kolejnym przedmiotem codziennego użytku, który zlokalizowano w nawarstwieniach obiektu 

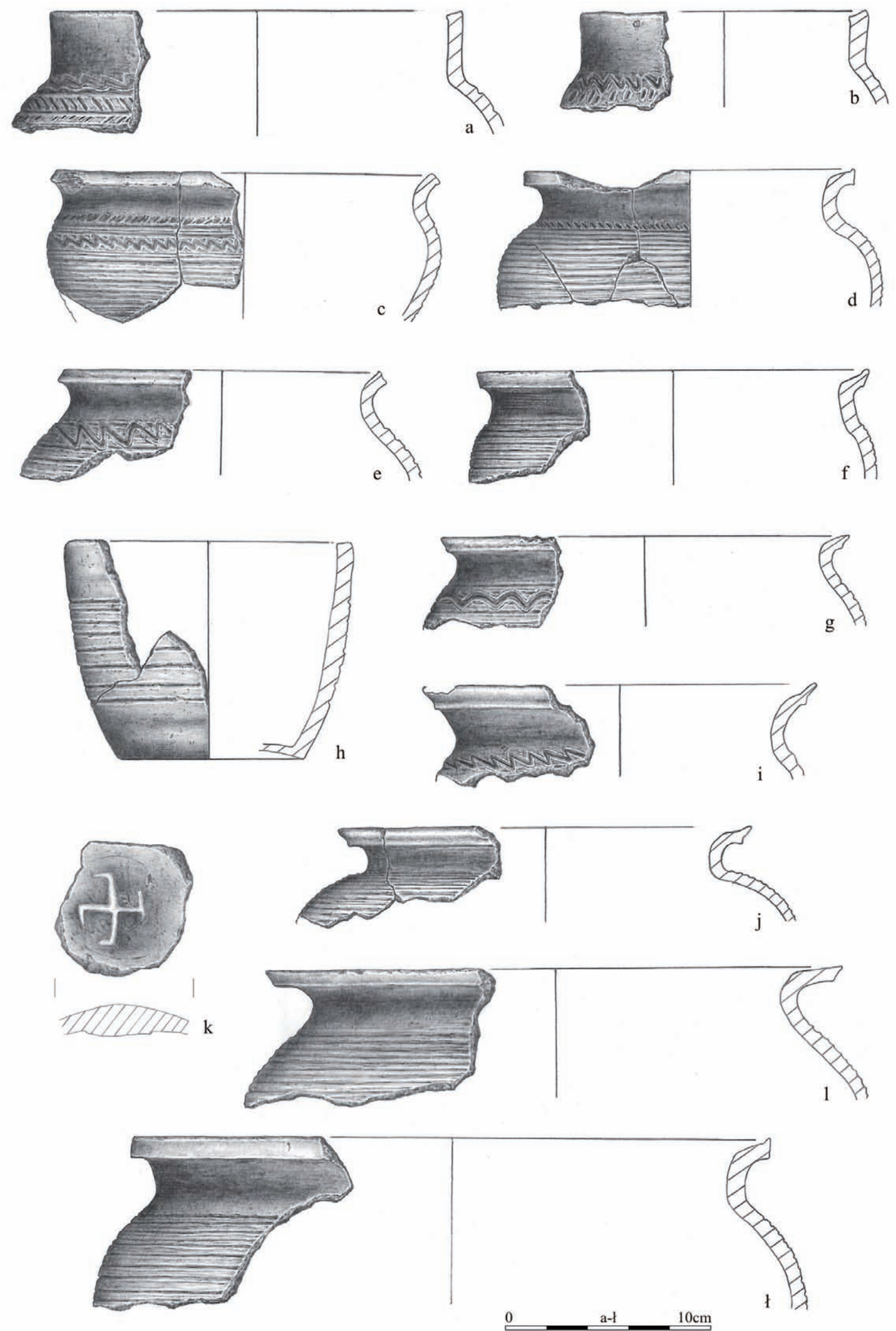

Ryc. 10. Kałdus, gm. Chełmno, woj. kujawsko-pomorskie. Naczynia ceramiczne z obiektu 172. GT V: a-ł. Warstwa I: a-ł. Rys. B. Kowalewska

Fig. 10. Kałdus, Chełmno district, the Kuyavian-Pomeranian Voivodeship. Pottery vessels from the feature 172. GT V: a-ł. Layer I: a-ł. Drawn by B. Kowalewska 


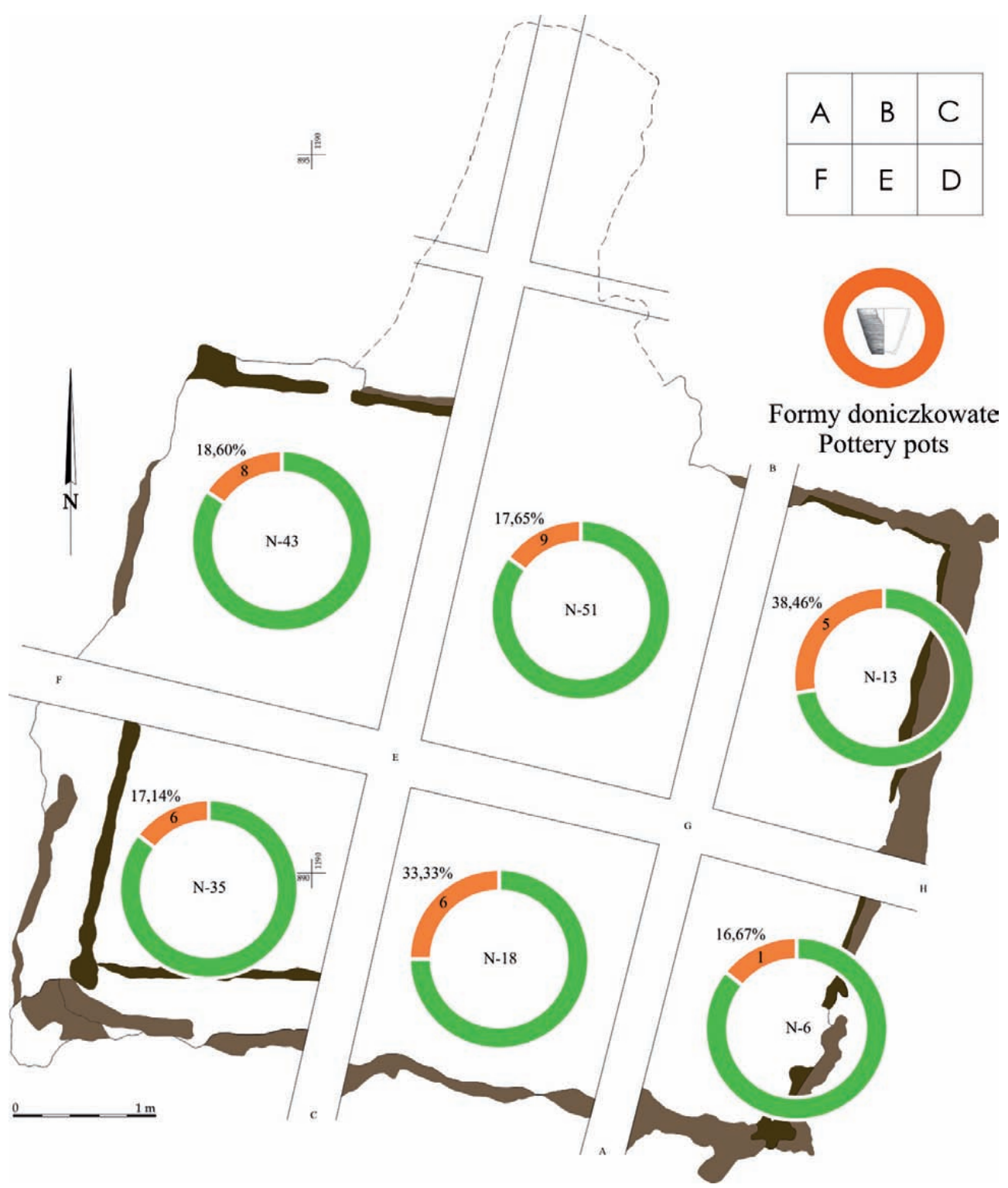

Ryc. 11. Kałdus, gm. Chełmno, woj. kujawsko-pomorskie, stanowisko 2. Domniemana karczma (obiekt 172).

Rozkład przestrzenny naczyń ceramicznych o formach doniczkowatych w ujęciu liczbowo-procentowym na tle wydzielonych działek badawczych A-F. Rys. M. Weinkauf

Fig. 11. Kałdus, Chełmno district, the Kuyavian-Pomeranian Voivodeship, site 2. The supposed inn (feature 172). The spatial distribution of pottery pots from numerical and percentage perspective with reference to the divided research plots A-F. Drawn by M. Weinkauf

172, jest klucz żelazny (ryc. 13: f). Charakteryzuje go duży, czworokątny uchwyt oraz płaskie pióro z jednym prostokątnym i trzema półkolistymi wcięciami. Tego typu klucze należą do wyjątkowych znalezisk; z osady podgrodowej w Kałdusie znany jest tylko jeden podobny egzemplarz (warstwa VI). Ponadto w pozostałościach budynku natrafiono na inne jeszcze narzędzia, które mogły stanowić standardowy zestaw przedmiotów, używanych przez jego mieszkańców. Zaliczyć do nich należy 3 haczyki do wędek, gwóźdź (ryc. 13: g-h) oraz skobel (ryc.
13: i). Odrębny zespół tworzą przedmioty żelazne (10 sztuk), których, z uwagi na zły stan ich zachowania, nie udało bliżej określić.

Z wytwórczością przędzalniczą i tkacką można powiązać trzy przęśliki ceramiczne (ryc. 13: s-u), których forma oraz technika wykonania nie różni się zasadniczo od egzemplarzy znanych dla tego okresu z pozostałych członów omawianego zespołu osadniczego. Są to okazy dwustożkowate o niezdobionej gładkiej powierzchni; dwa z nich (ryc. 13: t-u) charakteryzują się porównywalną wielkością, 


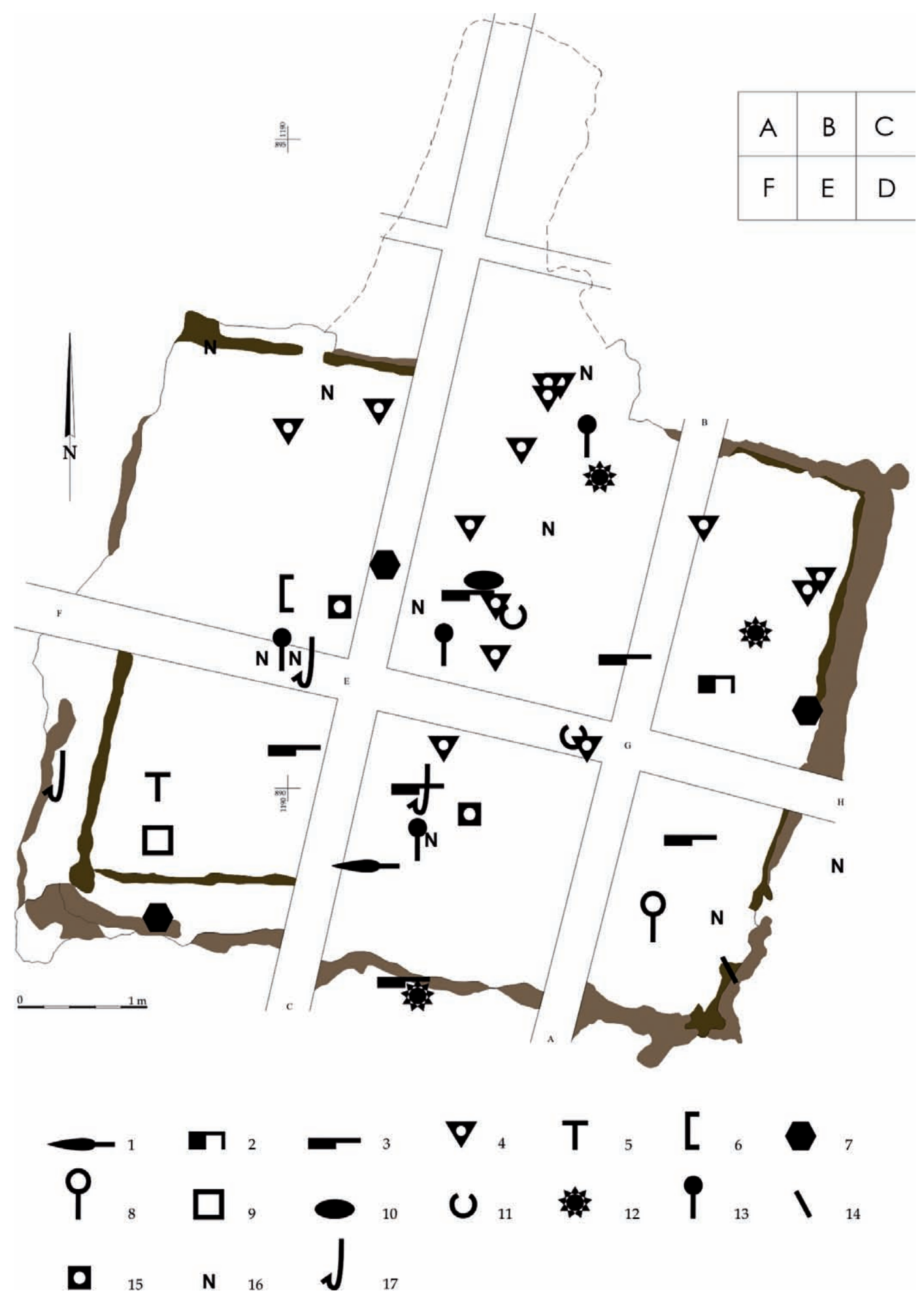

Ryc. 12. Kałdus, gm. Chełmno, woj. kujawsko-pomorskie, stanowisko 2. Domniemana karczma (obiekt 172). Planigrafia przedmiotów na tle wydzielonych działek badawczych A-F. Legenda: 1 - grot z żelaza; 2 - klucz z żelaza; 3 - nóż z żelaza; 4 - odpad z ołowiu; 5 - gwóźdź z żelaza; 6 - skobel z żelaza; 7 - przęślik z gliny; 8 - szpila ze stopu brązu; 9 -okucie ze stopu brązu; 10 - paciorek ze szkła; 11 - kabłączek ze stopu brązu; 12 -obrączka/pierścionek ze stopu brązu; 13 - igła z żelaza/kości; 14 - drut ze stopu brązu; 15 - spiek z żelaza; 16 - przedmiot nieokreślony; 17 - haczyk z żelaza. Rys. M. Weinkauf

Fig. 12. Kałdus, Chełmno district, the Kuyavian-Pomeranian Voivodeship, site 2. The supposed inn (feature 172). Planigraphy of artefacts with reference to the divided research plots A-F. Legend: 1 - an iron head; 2 - an iron key; 3 - an iron knife; 4 - a lead waste; 5 - an iron nail; 6 - an iron staple; 7 - a clay spindle whorl; 8 - a bronze alloy pin; 9 - a bronze alloy ferrule; 10 - a glass bead; 11 - a bronze alloy temple ring; 12 - a bronze alloy ring; 13 - an iron/bone needle; 14 - a bronze alloy wire; 15 - an iron sinter; 16 - an undefined object; 17 - an iron hook. Drawn by M. Weinkauf 

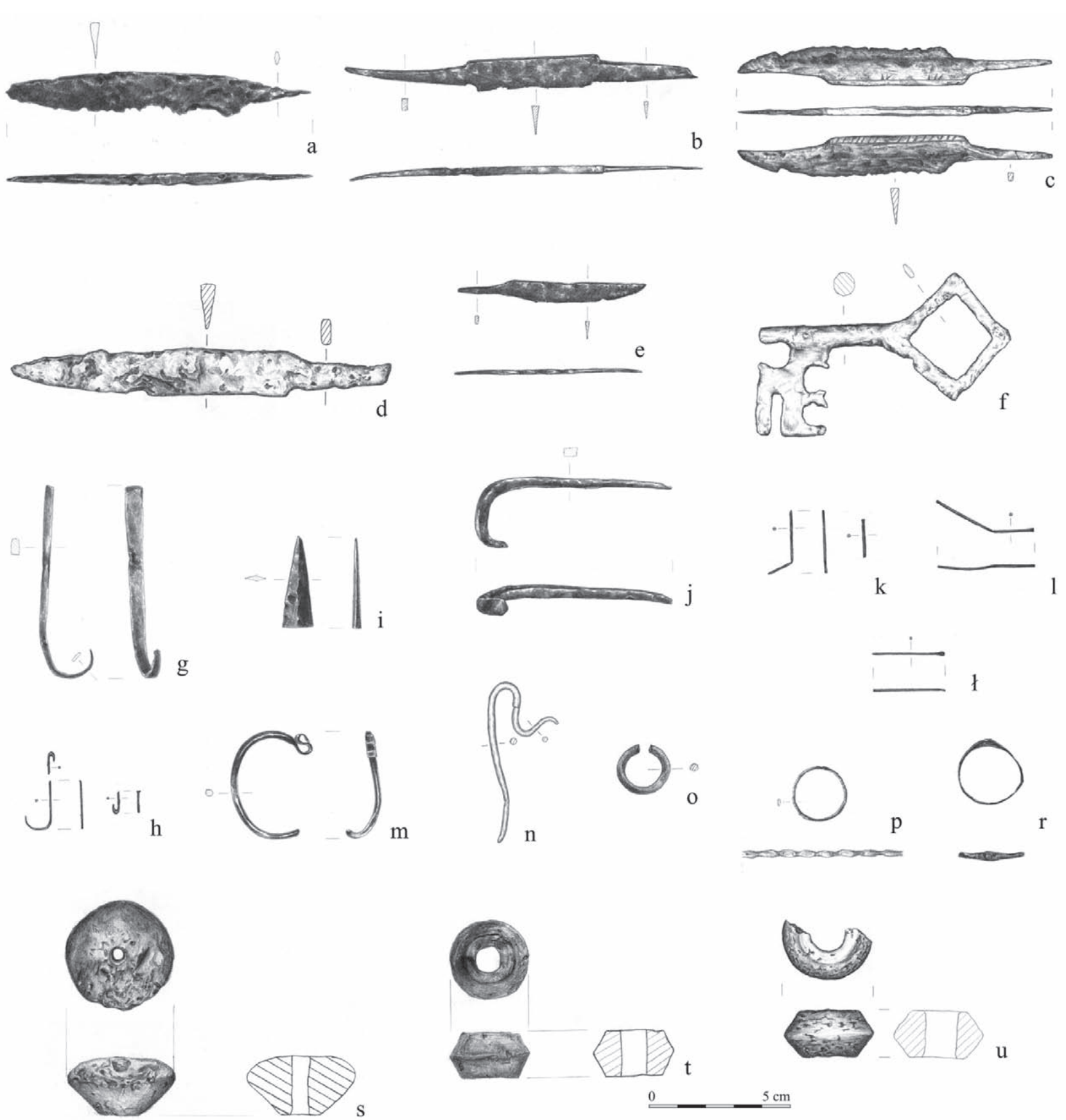

Ryc. 13. Kałdus, gm. Chełmno, woj. kujawsko-pomorskie. Wybrane przedmioty wydzielone z obiektu 172: nóż żelazny (a-e), klucz żelazny (f), haczyk żelazny (g-h), skobel żelazny (i), igła żelazna (j-1), grot żelazny (ł),

kabłączek skroniowy z brązu (m), szpila brązowa (n), obrączka brązowa (o), pierścionek brązowy (p-r), przęślik gliniany (s-u). Rys. A. Cedro, P. Ignaczak, B. Kowalewska, E. Kropidłowska

Fig. 13. Kałdus, Chełmno district, the Kuyavian-Pomeranian Voivodeship. Selected artefacts from the feature 172: iron knife (a-e), iron key (f), iron hook (g-h), iron staple (i), iron needle (j-1), iron arrowhead (ł), bronze temple ring $(\mathrm{m})$, bronze pin $(\mathrm{n})$, bronze band ring (o), bronze ring (p-r), clay spindle whorl (s-u).

Drawn by A. Cedro, P. Ignaczak, B. Kowalewska, E. Kropidłowska

jak i średnicą otworu, natomiast trzeci (ryc. 13: s) ma niewielki otwór i silnie ścięte boki. Do tej grupy narzędzi zaklasyfikowane zostały także trzy cienkie igły żelazne (ryc. 13: j-1) oraz jedna kościana.
W obrębie omawianego obiektu znajdowały się również drobne ozdoby, w tym dwa esowate kabłączki skroniowe typu IIIc wykonane $\mathrm{z}$ brązu (ryc. 13: m), dwa pierścionki brązowe (ryc. 13: p-r) 


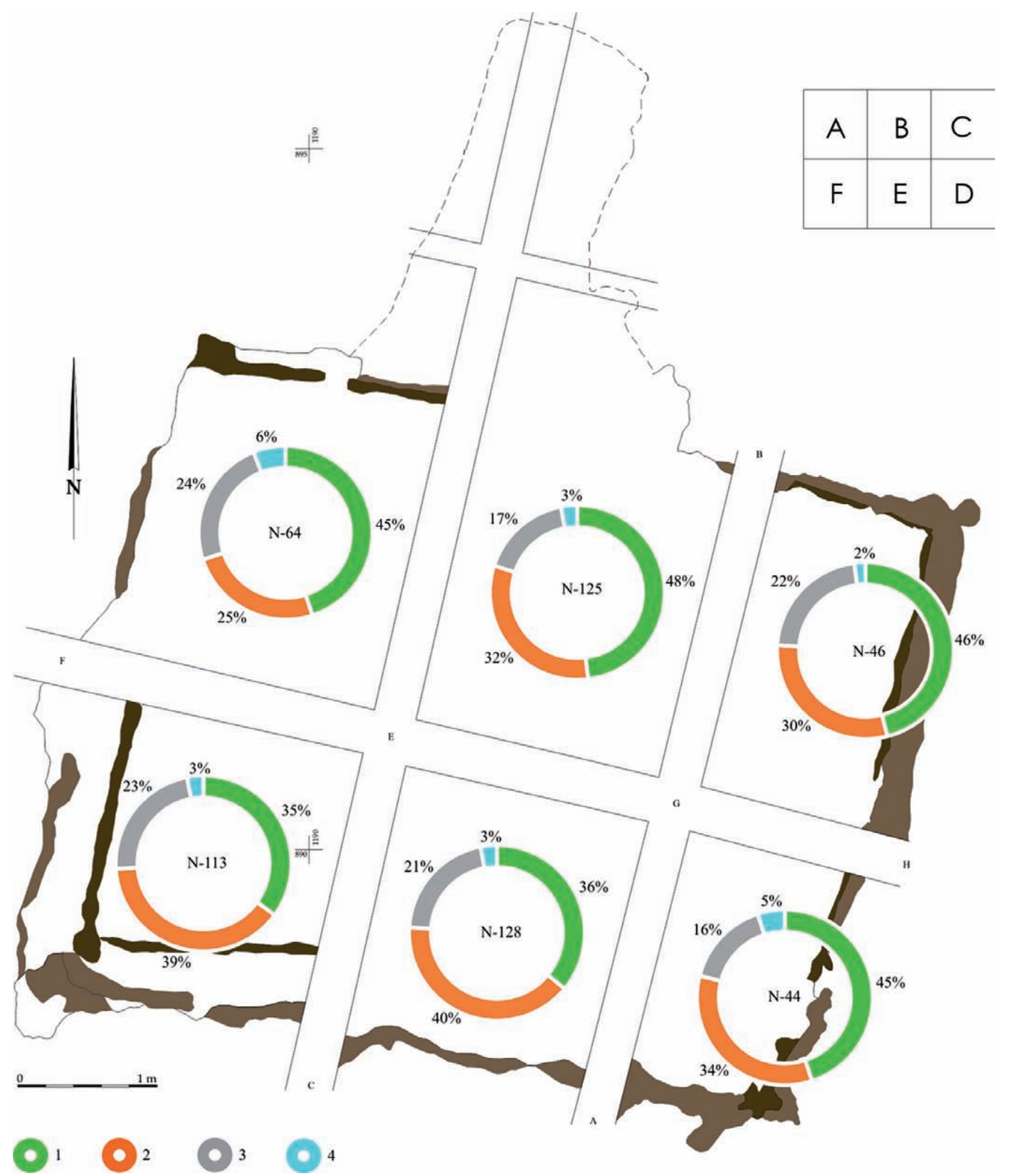

Ryc. 14. Kałdus, gm. Chełmno, woj. kujawsko-pomorskie, stanowisko 2. Domniemana karczma (obiekt 172). Rozkład przestrzenny gatunków zwierząt domowych w ujęciu liczbowo-procentowym na tle wydzielonych działek badawczych A-F. Legenda: 1 - bydło; 2 - świnia; 3 - owca/koza; 4 - koń. Rys. M. Weinkauf

Fig. 14. Kałdus, Chełmno district, the Kuyavian-Pomeranian Voivodeship, site 2. The supposed inn (feature 172). The spatial distribution of species of domestic animals from numerical and percentage perspective with reference to the divided research plots A-F. Legend: 1 - cattle; 2 - pig; 3 - sheep/goat; 4 - horse. Drawn by M. Weinkauf

ze zdobieniem w formie zgrubień (typ II i IV wg H. Kóčki-Krenz 1993), brązowa obrączka (ryc. 13: o) wykonana $\mathrm{z}$ okragłego w przekroju drutu (typ I wg H. Kóčki-Krenz 1993), fragment esowato wywiniętej szpili brązowej, służącej najprawdopodobniej do spinania ubrania (ryc. 13: n), niewielki paciorek z zielonego szkła, a także fragment okucia brązowego.
W warstwie I odkryto tylko jeden element uzbrojenia w postaci żelaznego grotu włóczni lub oszczepu o romboidalnym przekroju (ryc. 13: ^). $\mathrm{Z}$ uwagi na fragmentaryczne zachowanie ostrza grotu, nie jest możliwe przyporządkowanie go do konkretnego typu.

W obrębie budynku zadokumentowano również 14 fragmentów bryłek ołowiu (surowiec), je- 
den pręt brązowy oraz cztery spieki żelazne i ołowiane.

Kości zwierzęce. Źródła archeozoologiczne reprezentuja zróżnicowane pod względem gatunkowym materiały kostne liczące 1297 fragmentów $^{8}$ (Makowiecki 2004; 2010, aneks, 222). Wśród wyraźnie dominujących ilościowo kości ssaków domowych konsumpcyjnych $(87 \%$ określonych $)^{9}$ najwięcej wyróżniono szczątków bydła (Bos primigenius $\mathrm{f}$. taurus; $34,3 \%$ ), nieco mniej świni (Sus scrofa f. domestica; 288, czyli 30,5\%), wyraźnie mniej owcy/kozy (0 vis ammon f. aries/ Capra aegagrus f. hircus; 19,3\%) i konia (Equus ferus f. caballus; 2,9\%) (ryc. 14, tab. 2). Podobne relacje liczbowo-procentowe odnotowano dla materiału kostnego występującego niemal we wszystkich częściach analizowanego obiektu. Ssaki domowe drapieżne są reprezentowane jedynie przez pojedyncze kości - psa (Canis lupus f. familiaris; 1 ) i kota (F elis silvestris f. catus; 2 ). W grupie animalia minuta zidentyfikowano kości zająca (Lepus europaeus; 6), wiewiórki (Sciurus vulgaris; 1) i lisa (Vulpes vulpes; 1). Wśród zwierząt $\mathrm{z}$ grupy animalia superiora zaobserwowano udział szczątków jelenia (Cervus elaphus; 15), dzika (Sus scrofa; 12), sarny (Capreolus capreolus; 7) i niedźwiedzia brunatnego (U rsus arctos; 3) (łącznie 3,7\% szczątków kostnych). Znaczny udział $\mathrm{w}$ zespole analizowanej fauny stanowia ptaki (Aves; 52, czyli 5,5\%), w tym głównie kura (Gallus gallus f. domestica). Zidentyfikowano też kość bociana (Ciconia sp.). Z ryb (Pisces; 22, czyli 2,3\%) zwraca uwagę obecność gatunków o naturalnie dużych rozmiarach - jesiotra (Acipenser sp.), suma (Silurus glanis, powyżej $150 \mathrm{~cm}$ długości) i szczupaka (Esox lucius). Innym dosyć wyjątkowym ekofaktem jest obecność w obiekcie 172 aż trzech szczątków niedźwiedzia brunatnego, tj. dwóch kości łap i jednego zęba.

Makroszczątki roślinne. Na podstawie przeprowadzonych analiz paleobotanicznych wydzielone zostały pozostałości roślin uprawnych, synantropijnych, przemysłowych oraz gatunków flory

8 Na złożu wtórnym zadokumentowano kilka drobnych fragmentów kości ludzkich prawdopodobnie pochodzących z pobliskiego cmentarzyska szkieletowego.

9 Dla obiektu 172 przynależność gatunkową ustalono w stosunku do 944 kości na 1297 znalezionych. będących przedmiotem zbieractwa (Polcyn 2004; Abramów 2012). Tworzyły one zespół obejmujący 20 taksonów reprezentowanych w sumie przez 210 makroszczątków (ryc. 15, tab. 3). Przeważającą ich część stanowiły gatunki zbóż takich jak żyto zwyczajne (Secale cereale; 69, czyli 33,33\% ), jęczmień (H ordeum vulgare; 1, czyli 0,48\%), pszenica (Triticum aestivum; 7 , czyli 3,38\%), proso (Panicum miliaceum; 5, czyli 2,42\%) i owies (Avena sativa; 6, czyli 2,90\%), a także len ${ }^{10}$ (Linum usitatissimum; 1, czyli $0,48 \%$ ). Roślinom uprawnym towarzyszyły pozostałości chwastów w postaci nasion rdestówki powojowatej (Polygonum convolvulus), stokłosy żytniej (Bromus secalinus) oraz kąkolu polnego (Agrostemma githago). Na uwagę zasługuje również duża frekwencja szczątków grochu zwyczajnego (Pisum sativum). Ponadto odnotowano szczątki drzew w postaci fragmentów łupin leszczyny ( $\mathrm{C}$ rylus avellana) i graba (Carpinus betulus), pestki śliwy (Prunus domestica), wyki (Vicia $s p$.), buławinki czerwonej (Claviceps purpurea) oraz roślin motylkowatych (F abaceae).

Z obiektu 172 analizie antrakologicznej poddano 10 prób, w których oznaczono 246 fragmentów węgli drzewnych pobranych z północnej, północno-zachodniej i północno-wschodniej partii obiektu. Szczątki drewna zalegały przede wszystkim w brzeżnych częściach obiektu pochodzących zapewne z konstrukcji budynku. Należą one do trzech taksonów reprezentujących drzewa liściaste: brzozę (Betula sp.), dąb (Quercus sp.) i wiąz (Ulmus sp.). W największej liczbie zachowały się szczątki dębu (151 fragmentów) oraz brzozy (91 fragmentów). Pozostałości wiązu reprezentowane były w ilości śladowej (4 fragmenty). Znamienne jest to, że próby pobrane $\mathrm{z}$ obrzeża budynku zawierają głównie szczątki dębu, co można uznać za wskazówkę dla określenia rodzaju materiału budowlanego użytego do wzniesienia ścian bądź podłogi budynku.

Zestawiając podstawowe dane dotyczące rozkładu przestrzennego poszczególnych kategorii

10 Niewykluczone, że len mógł być wykorzystywany również w innym celu niż konsumpcyjny. Obecność przęślików sugerować może stosowanie tej rośliny w wytwórczości tekstylnej. Jednak brak bezpośrednich dowodów na takie przetwarzanie lnu, w postaci łodyg, jak i paździerzy, w materiale archeobotanicznym, skłania ku konsumpcyjnemu charakterowi znaleziska (por. Chmielewski 2009, 21 i n.). 


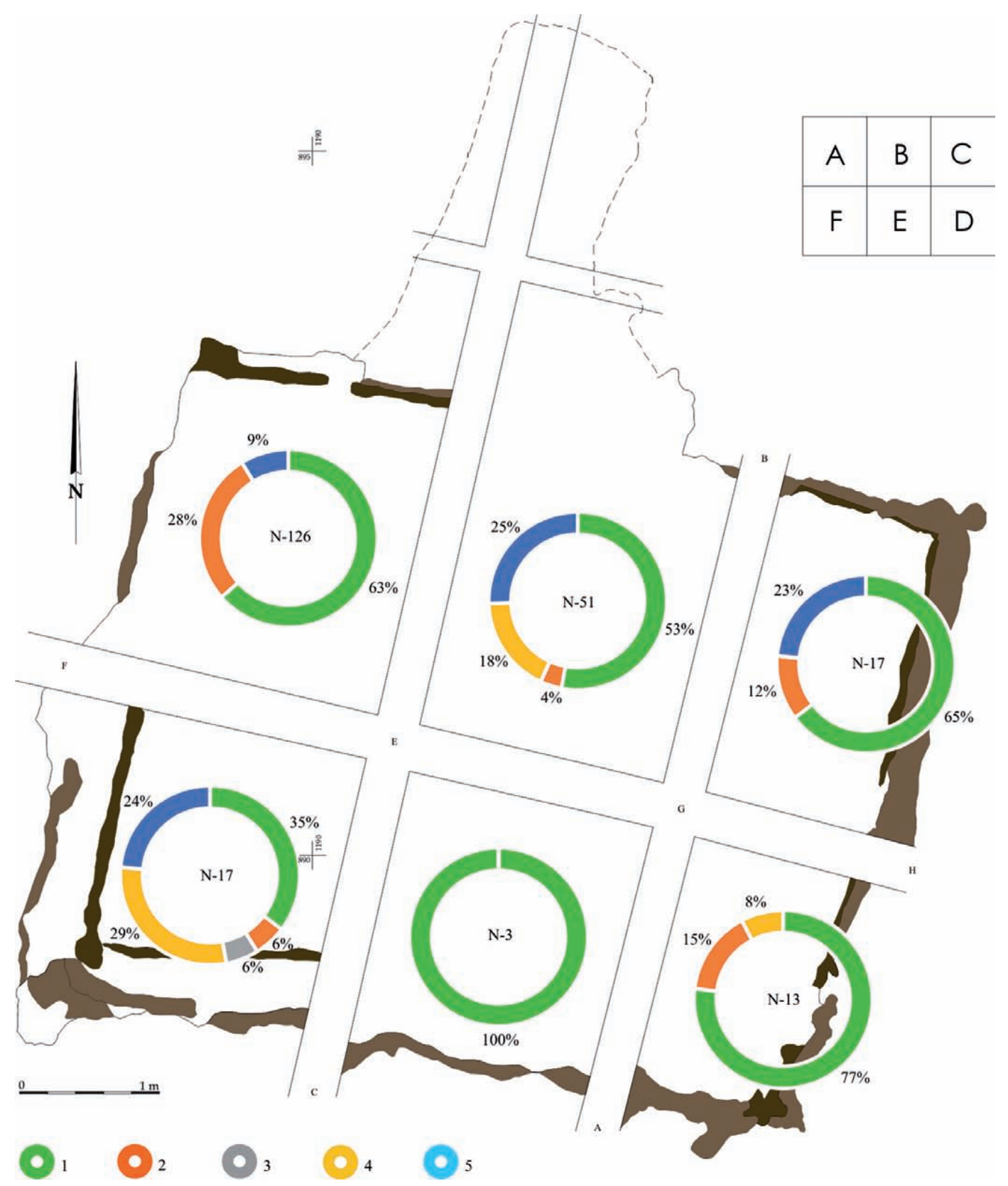

Ryc. 15. Kałdus, gm. Chełmno, woj. kujawsko-pomorskie, stanowisko 2. Domniemana karczma (obiekt 172). Rozkład przestrzenny podstawowych taksonów roślinnych w ujęciu liczbowo-procentowym na tle wydzielonych działek badawczych A-F. Legenda: 1 - zboża; 2 - strączkowe; 3 - oleiste; 4 - drzewa/krzewy; 5 - pozostałe.

Rys. M. Weinkauf

Fig. 15. Kałdus, Chełmno district, the Kuyavian-Pomeranian Voivodeship, site 2. The supposed inn (feature 172). The spatial distribution of basic plant taxa from numerical and percentage perspective with reference to the divided research plots A-F. Legend: 1 - cereal crops; 2 - leguminous plants; 3 - oil plants; 4 - trees/bushes; 5 - others.

Drawn by M. Weinkauf

źródeł można wnioskować o socjotopografii omawianego obiektu. Na szczególną uwagę zasługuje ich charakterystyczne rozplanowanie w odniesieniu do wydzielonych działek eksploracyjnych (A-F). Największe nagromadzenie różnych kategorii źródeł występowało w centralnej i zachodniej partii obiektu (części A, B, E, F) (tab. 1). Zadoku- mentowano tu obecność dużej liczby potłuczonych naczyń ceramicznych, niekiedy ze śladami osadu po wewnętrznej stronie (4 egzemplarze). $Z$ tej partii obiektu pochodzą między innymi naczynia zasobowe służące czasowemu przechowywaniu produktów płynnych i sypkich oraz występowanie okazów doniczkowatych, pełniących zapew- 
ne funkcję kubków. Na szczególną uwagę, z racji funkcji obiektu, zasługuje materiał archeobotaniczny, również koncentrujący się w zachodniej części obiektu (część A - 10 taksonów, 64 makroszczątki; część B - 12 taksonów, 47 makroszczątków; zob. tab. 3). Przeważały tu rośliny uprawne używane w przygotowywaniu produktów mącznych (Secale cereale, Triticum aestivum, Avena sativa, H ordeum, Panicum miliaceum). Znamienna jest tu również obecność orzechów laskowych (Corylus avellana; 7 okazów), grochu zwyczajnego (Pisum sativum; 35 okazów - wszystkie z północno-zachodniej partii obiektu), pojedynczych szczątków soczewicy jadalnej (Lens culinaris), lnu zwyczajnego i owoców śliwy. W materiałach faunistycznych zbiory z obu części były zdecydowanie liczniejsze niż w części wschodniej (tab. 2). Wśród kości zwierząt w centralnej i zachodniej części obiektu dominowały kości ssaków domowych, takich jak bydło (175 okazów), świnia (151 okazów), owca/koza (85 okazy) i koń (15 okazów). Wśród ssaków dzikich wystapiły głównie kości dzika (8 okazów), jelenia (7 okazów), sarny (4 okazy) i niedźwiedzia (2 okazy). Ponadto zaobserwowano szczątki ptactwa - kury, gęsi (domowe/dzikie) i dzikiej kaczki (25 okazów) oraz ryb (15 okazów). Pod tym względem wschodnia część obiektu była znacznie uboższa. Najprawdopodobniej to centralna i zachodnia część obiektu 172 spełniała funkcję gospodarcza - magazynową i kuchenną, a partia wschodnia budynku była zapewne ogólnodostępna, niewykluczone, że związana $\mathrm{z}$ konsumpcją.

\section{OBIEKT 172 NA TLE UKŁADU PRZESTRZENNO-FUNKCJONALNEGO OSADY PODGRODOWEJ}

$\mathrm{Na}$ podstawie dotychczasowego rozpoznania przestrzeni reliktowej osady podgrodowej w Kałdusie obejmującej przede wszystkim obszar stanowiska $2^{11}$, można wnioskować o występowaniu tu pozostałości wielodworczej zabudowy, zaznaczającej się w postaci kilku głównych skupisk obiektów osadniczych z okresu wczesnego średniowiecza. Relikty omawianego w niniejszym artykule budynku zlokalizowano w strefie największej koncentracji obiektów, jaką dotąd stwierdzono na przedpolu Góry św. Wawrzyńca. Prawdopodobnie głównie z okresem jego funkcjonowania (faza IX) można powiązać większość spośród ponad 70 jam o charakterze gospodarczo-produkcyjnym odsłoniętych

11 Zabudowa osady podgrodowej sięgała również obszarów przyporządkowanych w ewidencji konserwatorskiej jako stanowiska 1 i 4, zasadniczo użytkowanych jednak do celów sepulkralnych. w jego najbliższym sąsiedztwie, tworzących wraz z nim wyraźnie wyodrębniające się skupisko obiektów obejmujących około 4-5 arów powierzchni (ryc. 16). Jest to strefa podwyższonej zawartości fosforu przekraczającego średnio 6500 mk.kg wskazującej na zwiększoną w tym miejscu aktywność człowieka związaną z zamieszkaniem, działalnością gospodarczą lub koszarowaniem tu zwierząt (Bednarek i inni 2004, 202, ryc. 2).

Znamienne jest również, że w bezpośrednim sąsiedztwie obiektu 172 natrafiono na pozostałości starszego, częściowo zniszczonego przez niego, kolejnego budynku oznaczonego jako obiekt 240, pod względem wielkości i kształtu jedynego porównywalnego z obiektem 172. Najstarszą fazę jego użytkowania, datowaną na 2. połowę VII wieku (faza I) powiązano $\mathrm{z}$ zagłębioną $\mathrm{w}$ ziemię czworokątną jamą o zaokraglonych narożnikach. Kolejny etap użytkowania tego obiektu przypadł na 2. połowę

Na sąsiedniej stronie:

Ryc. 16. Kałdus, gm. Chełmno, woj. kujawsko-pomorskie, stanowisko 2. Funkcje obiektów osadniczych z 2. połowy XII - 1. ćwierci XIII wieku (IX faza) wchodzących w skład infrastruktury zagrody związanej z domniemaną karczmą (obiekt 172). Legenda: 1 - mieszkalna - mieszkalno/gospodarcza; 2 - rów; 3 - gospodarcza; 4 -piecowisko; 5 - produkcyjna; 6 - płot; 7 - wędzarnia; 8 - palenisko; 9 - nieokreślona; 10 - metalurgiczna. Rys. M. Weinkauf

Fig. 16. Kałdus, Chełmno district, the Kuyavian-Pomeranian Voivodeship, site 2. Functions of the settlement features from the $2^{\text {nd }}$ half of the $12^{\text {th }}$ - the first quarter of the $13^{\text {th }}$ century (the $9^{\text {th }}$ phase) included in the infrastructure of the farmstead related to the supposed inn (feature 172). Legend: 1 - residential/residential and productive function; 2 - a ditch; 3 - utility function; 4 -a kiln place; 5 - productive function; 6 - a fence; 7 - a smoking chamber; 8 - a hearth; 9 - undefined function; 10 - metallurgical function. Drawn by M. Weinkauf 


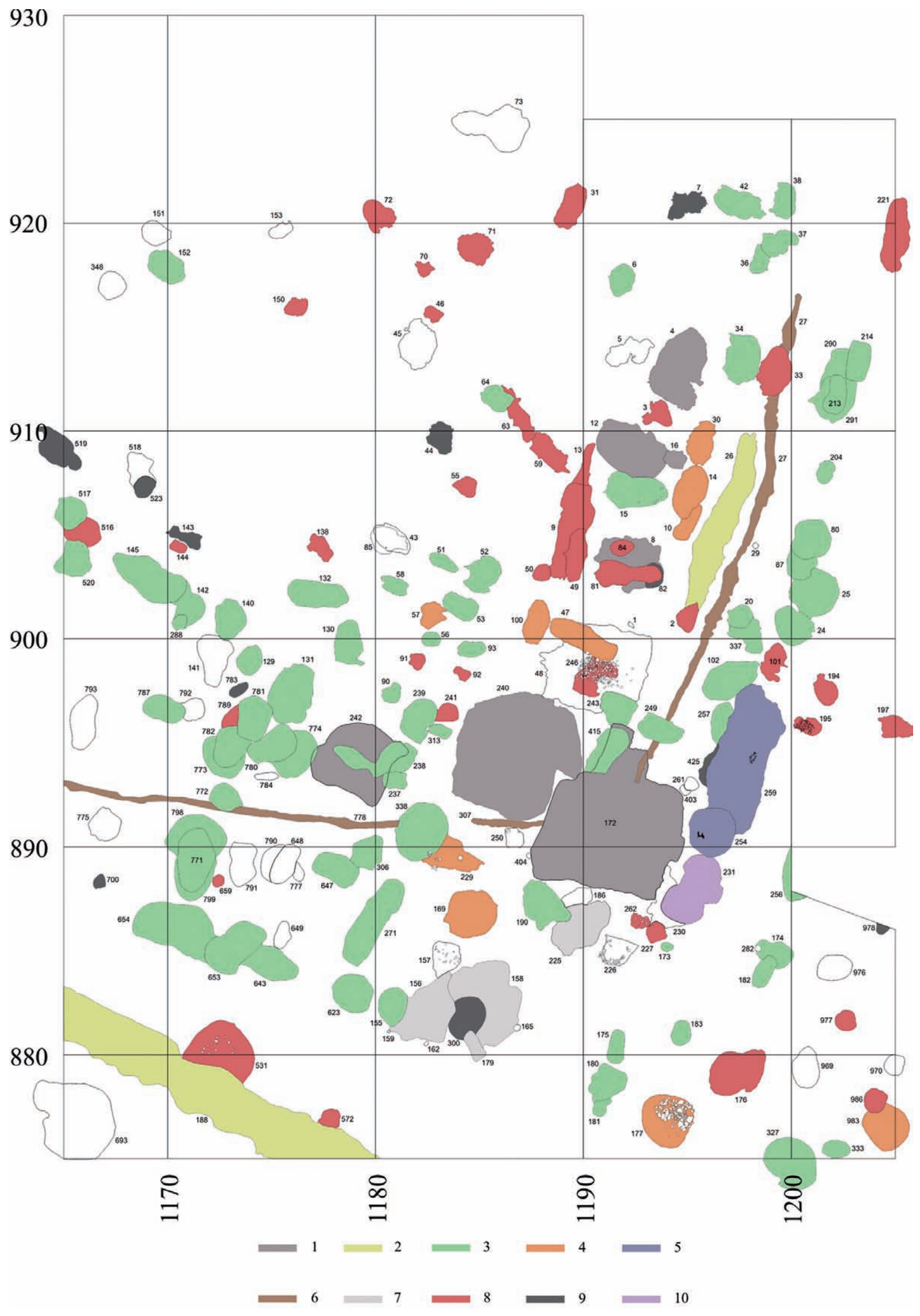


XI wieku i związany był ze wzniesieniem na planie kwadratu, częściowo zagłębionego, budynku o powierzchni $30 \mathrm{~m}^{2}$, wykonanego zapewne w konstrukcji zrębowej (faza VII). W tym samym miejscu w 1. połowie XII wieku (faza VIII) zbudowano kolejny, trochę większy, zapewne również zrębowy budynek, który około połowy XII wieku uległ zniszczeniu, a jego południowo-wschodni narożnik objęty został obrysem nowo budowanego obiektu 172 (Kalinowski 2007, 131). Ze względu na wielkość, kształt oraz obecność paleniska obiekt ten zaklasyfikowano jako pozostałość obiektu mieszkalnego.

Budynek 240 ulokowany był w południowo-zachodnim narożniku zagrody wydzielonej z przestrzeni drewnianymi ogrodzeniami (być może $\mathrm{w}$ formie palisady), których relikty czytelne są w postaci podłużnych płytkich rowów o szerokości 20-40 cm (obiekt 27, 307; ryc. 3). Długość ogrodzonej z trzech stron płotem zagrody wynosiła około 40 metrów, a jej szerokość około 1520 metrów. Jeżeli przyjąć, że jej ślady od północy nie uległy zatarciu, np. w wyniku erozji stokowej, to jest bardzo prawdopodobne, że była ona $\mathrm{z}$ tej strony otwarta. W tej części osady stwierdzono mniejszą koncentrację obiektów osadniczych, stąd wnioskować można, że obszar ten stanowił swego rodzaju dziedziniec, pusty majdan, służący do pozostawiania środków transportu (wozy, konie), jak i innego dobytku przetrzymywanego pod gołym niebem.

Układ ten uległ nieco zatarciu w okresie funkcjonowania budynku 172 posadowionego nie tylko na południowo-wschodnim narożniku budynku
240, ale również naruszającego strukturę rowu 27 oraz 307. Związanych z nim było wiele obiektów częściowo nawiązujących do przebiegu rowu (np. obiekty $231,254,259,24-25,87-80$ od strony wschodniej oraz 306, 367 od strony południowej) lub go niszczących (obiekty 338, 249, 33). Tworzyły one regularny miejscami układ obiektów, których koncentracja wyróżnia się na tle pozostałej części osady. Najwyraźniej zaznacza się to od strony południowej, gdzie obiekty występujące w układzie liniowym graniczyły bezpośrednio ze starym cmentarzem użytkowanym zapewne głównie w 2. połowie XI i w 1. połowie XII wieku. Obiekty, które przypisać należałoby do omawianego skupiska, odznaczały się dużym zróżnicowaniem formalnym, co wskazywałoby na ich różne przeznaczenie. Od północnej i zachodniej strony budynku 172 występowały pozostałości licznych piecowisk i palenisk, z których na uwagę zasługuje obiekt 246 leżący najbliżej jego wejścia - skupisko przepalonych kamieni, które można uznać za relikt pieca wolnostojącego. Bezpośrednio na wschód od niego odsłonięto szereg kolejnych jam, w tym trzy związane $\mathrm{z}$ działalnością metalurgiczną (obiekty 231, 254 i 259), o czym świadczyłaby duża liczba półproduktów i odpadów z ołowiu, analogicznych do tych odkrytych w obiekcie 172 . W obiekcie tym, jak i w najbliższym jego sąsiedztwie, natrafiono ponadto na liczne narzędzia kowalskie, co potwierdza profil prowadzonej $\mathrm{w}$ tym miejscu działalności. (m.in. szczypce, dłuta, szydła żelazne itp.). Obecność ewentualnej pracowni metalurgicznej potwierdza również fragment formy odlewniczej występującej w obiekcie 47 (ryc. 17).

Na sąsiedniej stronie:

Ryc. 17. Kałdus, gm. Chełmno, woj. kujawsko-pomorskie, stanowisko 2. Planigrafia przedmiotów na tle obiektów osadniczych z 2. połowy XII - 1. ćwierci XIII wieku (IX faza) wchodzących w skład infrastruktury zagrody związanej z domniemaną karczmą (obiekt 172). 17. Legenda: 1 - instrumenty muzyczne z kości; 2 - klucz z żelaza; 3 - krzesiwo z żelaza; 4 - oścień z kości; 5 - topór z żelaza; 6 - dłuto z żelaza; 7 - kłódka z żelaza; 8 - nożyce z żelaza; 9 - strzemię z żelaza; 10 - półprodukt z poroża; 11 - forma z gliny; 12 - grot z żelaza; 13 - oprawka z poroża; 14 - szczypce z żelaza; 15 - zawieszka ze stopu brązu; 16 - grzechotka z gliny; 17 - krążek z poroża; 18 - ostroga z żelaza; 19 - świder z żelaza; 20 - figurka z gliny; 21 - kości i pionki do gier z poroża; 22 - pionek z bursztynu; 23 - sierp z żelaza; 24 - igielnik z poroża. Rys. M. Weinkauf

Fig. 17. Kałdus, Chełmno district, the Kuyavian-Pomeranian Voivodeship, site 2. Planigraphy of artefacts with reference to the settlement features from the $2^{\text {nd }}$ half of the $12^{\text {th }}-$ the first quarter of the $13^{\text {th }}$ century (the $9^{\text {th }}$ phase) included in the infrastructure of the farmstead related to the supposed inn (feature 172). 17. Legend: 1 - bone musical instruments; 2 - an iron key; 3 - an iron fire striker; 4 - oa bone prod; 5 - an iron battleaxe; 6 - an iron chisel;

7 - an iron padlock; 8 - iron scissors; 9 - an iron stirrup; 10 - an antlers half-finished product; 11 - a clay mould; 12 - an iron head; 13 - an antlers rim; 14 - iron tongs; 15 - a bronze alloy pendant; 16 - a clay rattle; 17 - an antlers circle; 18 - an iron spur; 19 - an iron gimlet; 20 - a clay figurine; 21 - antlers dice and pawns; 22 - an amber pawn; 23 - an iron sickle; 24 - an antlers needle-case. Drawn by M. Weinkauf 


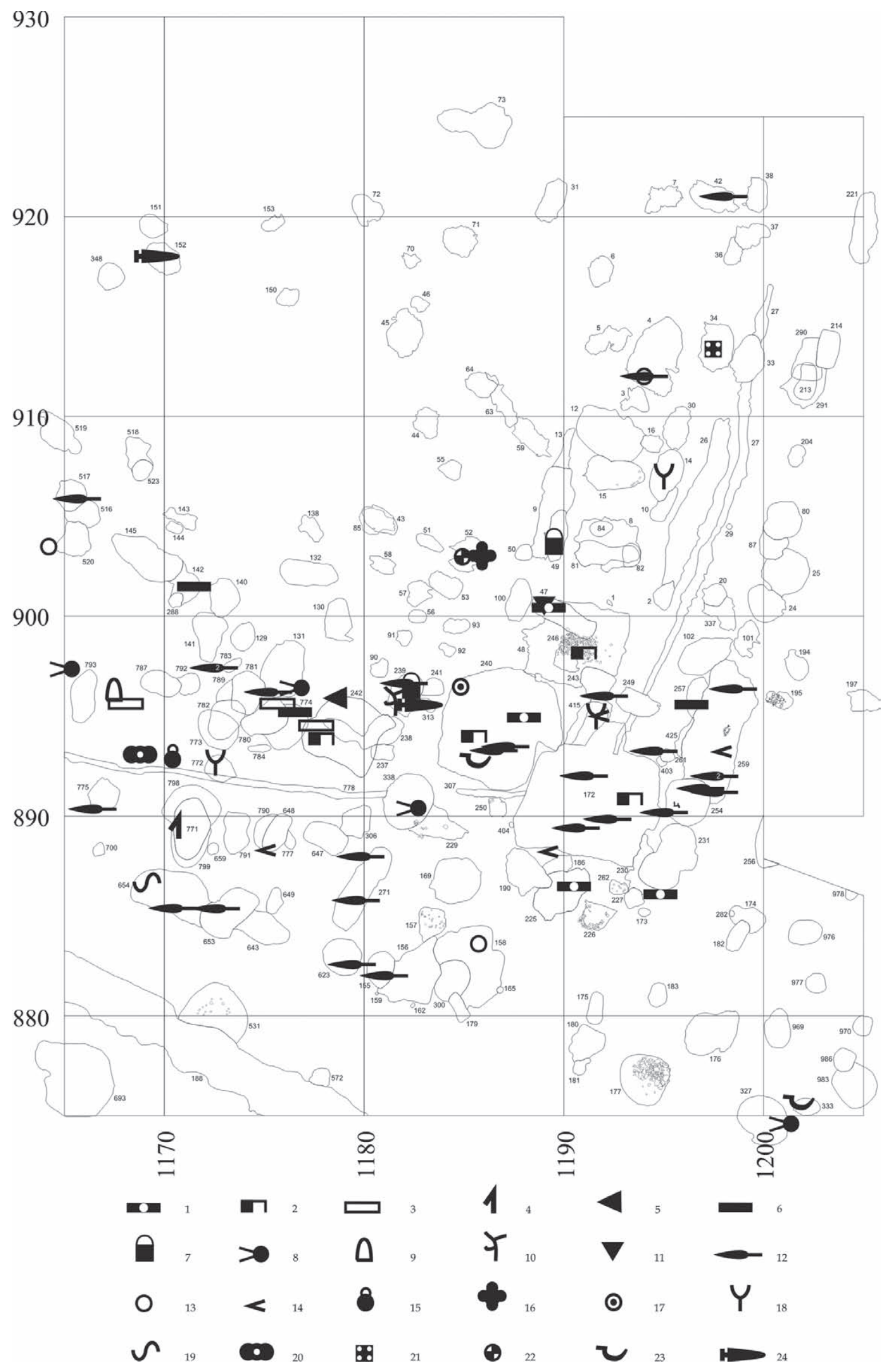




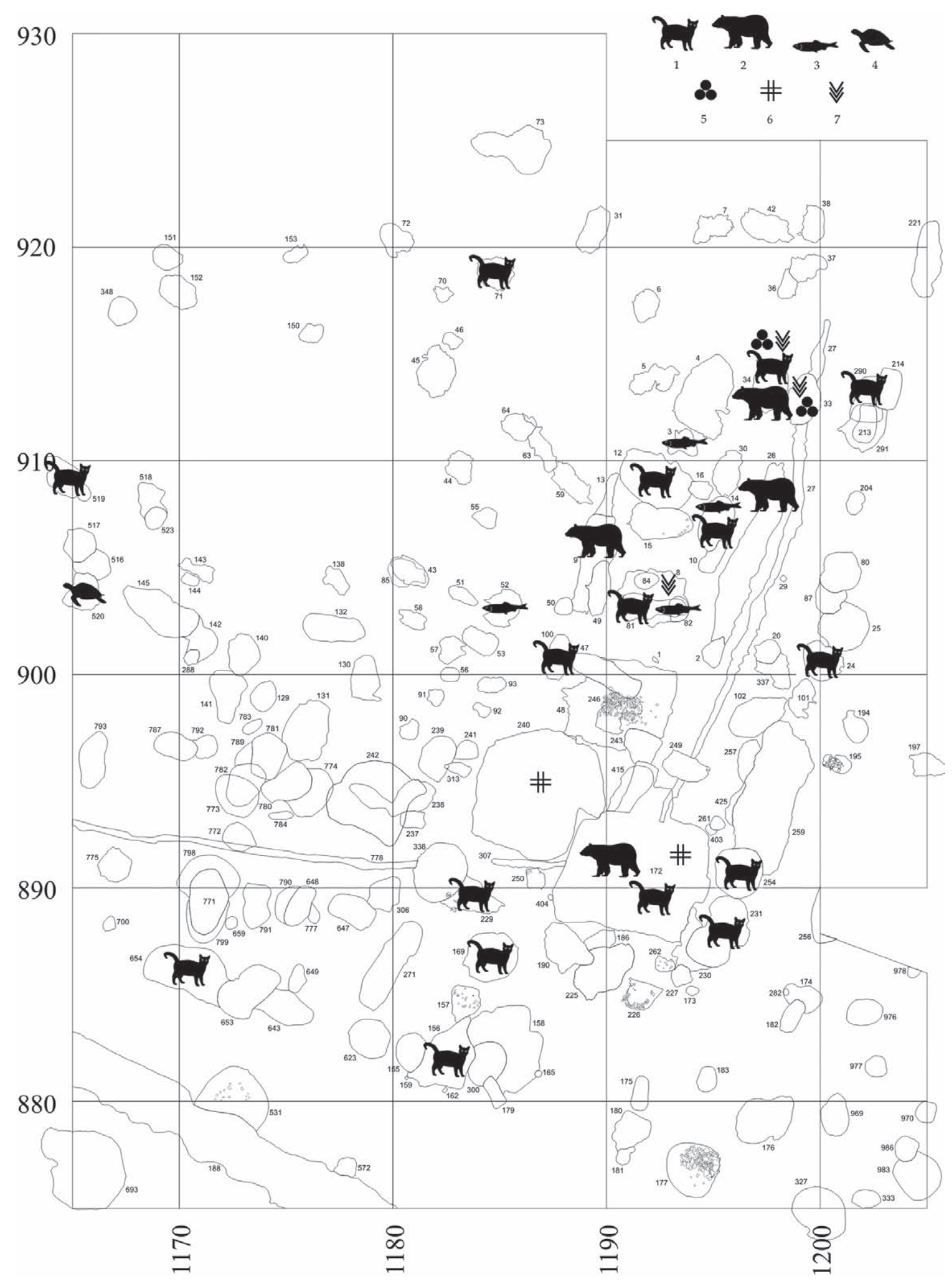

Ryc. 18. Kałdus, gm. Chełmno, woj. kujawsko-pomorskie, stanowisko 2. Planigrafia wybranych gatunków zwierząt i taksonów roślin na tle obiektów osadniczych z 2. połowy XII - 1. ćwierci XIII wieku (IX faza) wchodzących w skład infrastruktury zagrody związanej z domniemaną karczmą (obiekt 172). Legenda: 1 - kot; 2 - niedźwiedź; 3 -śledź; 4 -żółw; 5 - groch; 6 - len; 7 -żyto. Rys. M. Weinkauf

Fig. 18. Kałdus, Chełmno district, the Kuyavian-Pomeranian Voivodeship, site 2. Planigraphy of selected animal species and plant taxa with reference to the settlement features from the $2^{\text {nd }}$ half of the $12^{\text {th }}$ - the first quarter of the $13^{\text {th }}$ century (the $9^{\text {th }}$ phase) included in the infrastructure of the farmstead related to the supposed inn (feature 172).

Legend: 1 - a cat; 2 - a bear; 3 - a herring; 4 - a tortoise; 5 - pea; 6 - flax; 7 - rye. Drawn by M. Weinkauf 
Zupełnie inny charakter miały natomiast obiekty usytuowane po stronie południowej budynku 172 wzdłuż rowu odprowadzającego nadmiar wody w kierunku doliny Wisły, związane z działalnością wędzarniczą (obiekty 156, 158, 225). Na uwagę zasługuje również obiekt 239, gdzie natrafiono na ślady wytwórczości rogowiarskiej. Dodatkowo w bezpośrednim otoczeniu budynku 172 - w warstwach i jamach kulturowych - zaobserwowano znaczne nagromadzenie innych ważnych znalezisk, ściśle związanych z funkcją tego miejsca - przede wszystkim utensyliów kupieckich, takich jak fragmenty wag, odważniki (10 sztuk) i monety (4 sztuki). Tego rodzaju przedmioty występowały również w dużych ilościach poza skupiskiem obiektów związanych z omawianym budynkiem, choć ich związek przestrzenny właśnie $\mathrm{z}$ tą partią osiedla jest ewidentny i niewykluczone, że wskazuje na jej funkcje targowe. W wielu obiektach odkryto ponadto broń i części oporządzenia jeździeckiego, takie jak ostrogi czy wędzidła, co świadczy o przebywaniu w tym miejscu przedstawicieli elit społecznych. Inną kategorią źródeł, którą warto wymienić, potwierdzającą ten domysł są również liczne przedmioty związane z rekreacją i magią (kość do gry - 1 sztuka, pionek do gier planszowych - 1 sztuka, instrumenty muzyczne -4 sztuki).

W omawianym kontekście należy uwzględnić również niektóre znaleziska archeozologiczne odsłonięte na zapleczu budynku 172. W spagowej partii obiektu 259, stanowiącego część warsztatu metalurgicznego, odkryto kości całego prawego udźca bydlęcego. Można je uznać za pozostałości dużej części zakonserwowanej tuszy (np. poprzez wędzenie) jako zapas mięsa przeznaczonego do konsumpcji. Poza tym, z tego samego osobnika pochodziły fragmenty trzech kręgów lędźwiowych, na których stwierdzono ślady ostrego narzędzia. Mogły one powstać podczas odcinania partii lędźwiowej najdłuższego mięśnia grzbietu, który znany jest we współczesnej kuchni jako jedna z najwartościowszych części tuszy wołowej pod nazwą rostbef (Makowiecki 2010, 144; por. także Sobociński 1977). W sąsiednim obiekcie 254 odkryto wyjątkowe w skali osady znalezisko w postaci dwóch szkieletów kotów w układzie anatomicznym ${ }^{12}$ (ryc. 18; por. Chudziak 2003, 109-110; Błędowski, Chudziak, Weinkauf 2007, 254; Makowiecki 2010,

12 W publikacji z XV Sesji Pomorzoznawczej zamieniono omyłkowo numery obiektów.
143). Oba depozyty kostne można według wszelkiego prawdopodobieństwa traktować jako ślad zabiegów o charakterze apotropeicznym (por. Bajburin 1990; Baron 2012). Na uwagę zwraca również obecność w pobliżu budynku 172 szczątków śledzi. Zidentyfikowano je w czterech obiektach $(3,14,52$ i 82) i co ważne, nie odnotowano ich występowania $\mathrm{w}$ innych częściach osady. Jak wiadomo, śledź $\mathrm{w}$ tym czasie był jedyną rybą morską o znaczeniu handlowym, mającym związek $\mathrm{z}$ upowszechnianiem postów (ryc. 18; por. Makowiecki 2003). Interesujące jest również, iż podobnie jak w budynku 172, tak i w najbliższym jego sąsiedztwie (obiekty 9, 26 i 34) zarejestrowano kolejne szczątki niedźwiedzia reprezentowane przez łapy i głowy, stanowiące przysmak kulinarny (Kromer 1853, 31; Łoziński 1978, 221; Kiersnowski 1990, 47). I tym razem jest to jedyny rejon w przestrzeni całej osady, w którym odnotowano szczątki wymienionego gatunku. Warto też dodać, iż w literaturze historycznej przytaczane są informacje o niedźwiedziach w Europie Zachodniej trzymanych w łańcuchach podczas pokazów urządzanych przez niedźwiedników (XII-XIII wiek). Tresowane zaś sztuki używano do ćwiczeń sprawnościowych młodych elit (Samsonowicz 2011, 55), zaś w Skandynawii do stróżowania domostw (Kiersnowski 1990, 148).

Interesujących wyników dostarczyły również analizy materiałów archeobotanicznych pochodzących z najbliższego sąsiedztwa obiektu 172 , w tym obiektu 240 oraz z jamy zasobowej 34 . W kontekście udziału poszczególnych gatunków zbóż stwierdzonych w obiekcie 172, należy przypuszczać, że podstawowym w tym okresie użytkowanym zbożem było żyto zwyczajne (Secale cereale), a dopiero w dalszej kolejności proso zwyczajne (Panicum miliaceum), a za nim pszenica zwyczajna (Triticum aestivum) i jęczmień zwyczajny (H ordeum vulgare). Tendencja wzrostu znaczenia upraw żyta kosztem pszenicy stwierdzona została dla tego okresu w wielu innych regionach Polski (Badura 2009; Dembińska 1978b; Klichowska 1972; Lityńska-Zając 1997; 2010) i północnej Europy (Behre 1992). Z kolei, spadek znaczenia prosa na rzecz żyta tłumaczy się wzrostem znaczenia upraw zbóż chlebowych i spożyciem prosa głównie w kręgu uboższych warstw społecznych (Lityńska-Zając i in. 2010, 120). Udział poszczególnych gatunków zbóż może wskazywać zatem na zmiany, jakie zaszły nie tylko w sposobie uprawy roli (np. porzucenie systemu wypaleniskowego i stosowanie stałej uprawy, 


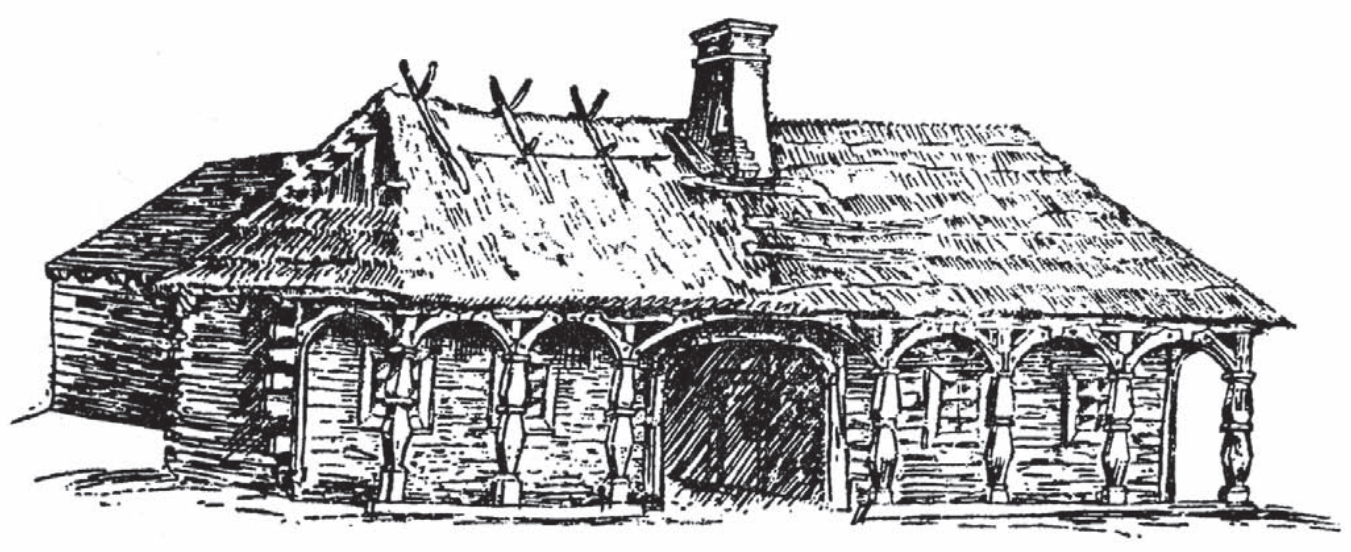

a

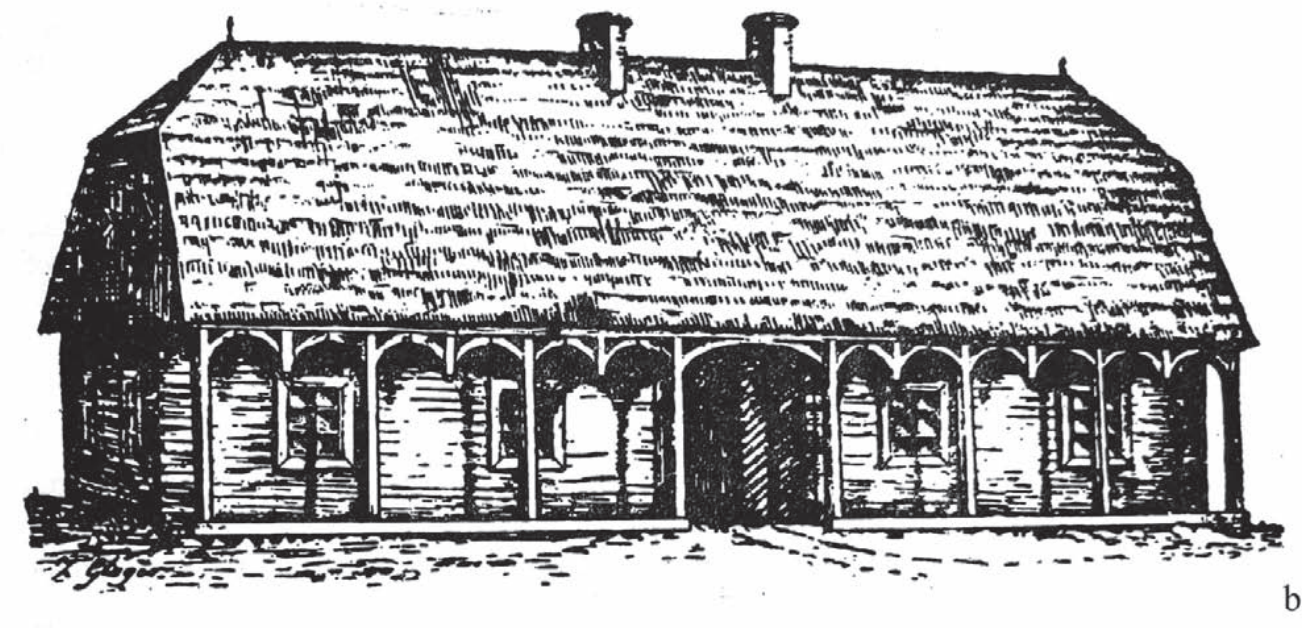

Ryc. 19. Przykłady karczem staropolskich: a - stara karczma polska wg szkicu Orłowskiego z 1817 r. (Gloger 1910, 11, fig. 3); b - zajazd szerokofrontowy w Osowcu nad Biebrzą z XVIII w. (Baranowski 1979, 17, fig. 9)

Fig. 19. Examples of old Polish inns: a - an old Polish inn according to a sketch by Orłowski from 1817 (Gloger 1910 , 11, fig. 3); b - a wide-front inn from Osowiec on the Biebrza from the $18^{\text {th }}$ century (Baranowski 1979, 17, fig. 9)

bardziej zaawansowanej techniki orki), ale także w lokalnej sytuacji społecznej. Powiększająca się liczba mieszkańców osady podgrodowej wymaga- ła zwiększenia produkcji mąki na pieczywo, ale także innych produktów spożywczych, włącznie $\mathrm{z}$ mięsem.

\section{INTERPRETACJA FUNKCJI OBIEKTU 172}

W świetle wyników przeprowadzonej analizy uwzględniającej cechy formalne budynku (obiektu 172), specyfikę występującego w jego obrębie zespołu źródeł ruchomych, kontekst osadniczy i historyczny można sformułować hipotezę dotyczącą funkcji omawianego obiektu. Charakteryzuje się on wieloma cechami, które pozwalają w nim widzieć pozostałości karczmy funkcjonującej na przedpolu Góry św. Wawrzyńca w 2. połowie XII i 1. ćwierci XIII wieku. Do najważniejszych zaliczyć należy:

a) przesłanki makrotopograficzne, a zwłaszcza lokalizację zespołu osadniczego in Culmine, stanowiącego najwyższe w hierarchii regionu miejsce centralne, bezpośrednio przy przeprawie przez Wisłę, w ważnym węźle komunikacyjnym łączącym najważniejsze w regionie szlaki dalekosiężne;

b) przesłanki mikrotopograficzne, a zwłaszcza charakterystyczne położenie obiektu, na niewielkiej kulminacji, bezpośrednio przy trakcie komunikacyjnym prowadzącym w kierunku przeprawy na Wiśle, niedaleko bramy wjazdowej wiodącej do grodu kasztelańskiego, co zapewniało jego kontrolę przez zarządców grodu; 


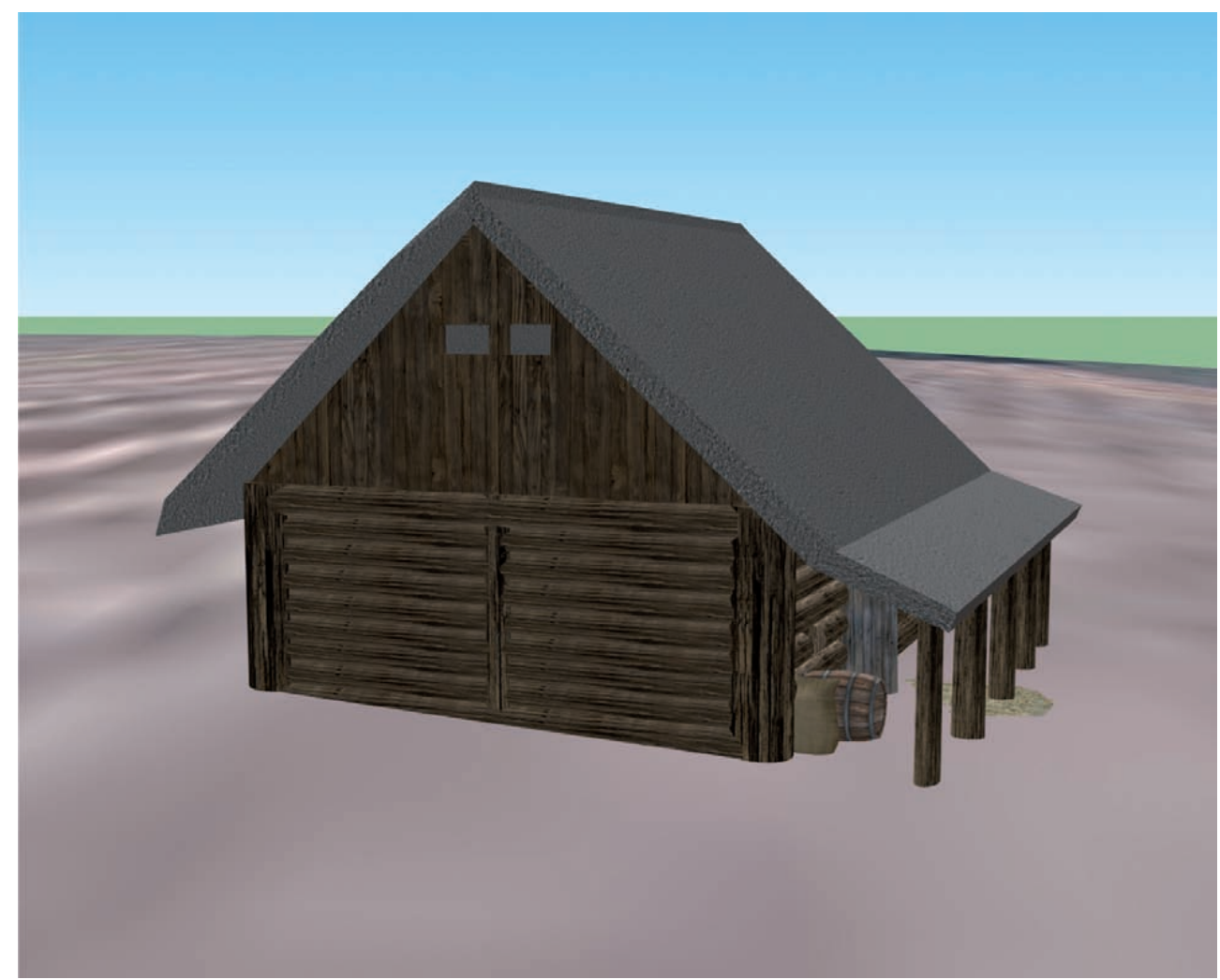

Ryc. 20. Rekonstrukcja domniemanej karczmy z Kałdusa. Oprac. Ł. Czyżewski Fig. 20. Reconstruction of the supposed inn from Kałdus. Elaborated by Ł. Czyżewski

c) wyjątkowa w skali całej osady podgrodowej wielkość budynku umożliwiająca pełnienie przez niego wielu funkcji społeczno-gospodarczych i politycznych przypisywanych karczmom na podstawie źródeł pisanych;

d) specyficzna konstrukcja sumikowo-łątkowa $\mathrm{z}$ podcieniem, często występującym w źródłach etnograficznych w kontekście karczem; podcień wsparty na pięciu słupach równomiernie rozmieszczonych wzdłuż ściany frontowej, stanowił zapewne dobrze widoczny z daleka ,znak rozpoznawczy” wyróżniający ten budynek na tle standardowej zabudowy osady (ryc. 19);

e) skupisko związanych z nim obiektów gospodarczo-produkcyjnych, świadczących, że omawiany obiekt stanowił centrum dużej zagrody obejmującej powierzchnię kilku arów; pozwalało to pełnić funkcje przypisywane tego rodzaju miejscom, włącznie z działalnością usługową, wymianą i różnymi rodzajami wytwórczości;

f) liczne utensylia kupieckie, monety, jak również przedmioty związane z rozrywką i magią itp. wskazujące na funkcje targowe samego budynku, jak i jego najbliższego zaplecza; g) liczne przedmioty związane ze sferą wytwórczości rzemieślniczej, przede wszystkim świadectwa metalurgii kolorowej i kowalstwa związanego niewątpliwie $\mathrm{z}$ transportem;

h) zespół źródeł archeobotanicznych i archeozoologicznych odzwierciedlających konsumpcyjne znaczenia tego miejsca; zakładając specyficzną funkcję społeczną karczmy, można przyjąć, iż była ona pod tym względem miejscem szczególnym, co potwierdzają liczne szczątki flory (zboża, groch, len) i fauny (bydło, trzoda chlewna ale również niedźwiedź i śledź) znalezione w obrębie budynku i w jego najbliższym sąsiedztwie;

i) pozostałości stwierdzonej w tej części terenu wielofazowej zabudowy mieszkalnej (obiekt 172 i 240) wskazującej na „długą tradycję” użytkowania tego miejsca, co zgodne jest z zasadą długiego trwania elementów infrastruktury komunikacyjnej, tak dobrze czytelną w przypadku traktów i przepraw.

Domniemany budynek karczmy wzniesiony w technice sumikowo-łątkowej uznać należy niewattpliwie za obiekt wyjątkowy w skali budownic- 
twa Słowiańszczyzny zachodniej (ryc. 20). Byłoby to pierwsze odkrycie z ziem polskich karczmy o tak wczesnej chronologii poświadczone przez szereg danych źródłowych mogących stanowić wskaźniki identyfikacji tego rodzaju obiektów. Niewykluczone, że powstał on w miejscu wcześniejszego budynku z 2. połowy XI i XII wieku (obiekt 240). Ulokowanie go na obszarze o tradycji osadniczej sięgającej VII wieku, w bezpośrednim sąsiedztwie grodu skupiającego funkcje administracyjne, polityczne i religijne, wydaje się być jak najbardziej uzasadnione i logiczne. Potwierdzeniem tego faktu jest wzmiankowany już kilkukrotnie falsyfikat mogileński, w którym o istnieniu targu i karczmy mówi się wprost. Oczywiście trudno w sposób kategoryczny łączyć historyczny zapis o karczmie z pozostałościami omawianego budynku. Niemniej, w świetle przedstawionych faktów, wydaje się, że takie wnioskowanie ma znaczny walor prawdopodobieństwa. Wyraźne wyniesienie terenowe, na którym znajdowało się osiedle, predestynowało centralną jego partię do wzniesienia budynku karczmy, co mogło wiązać się z odczuwaną przez mieszkańców szczególną aurą tego miejsca, swoistego genius loci, w obrębie którego kontakty międzyludzkie nabierały dodatkowego wymiaru.

Tabela 1. Kałdus, gm. Chełmno, woj. kujawsko-pomorskie, stanowisko 2. Domniemana karczma (obiekt 172). Grupy form naczyń oraz ich liczebność na tle wydzielonych działek badawczych A-F

\begin{tabular}{|c|c|c|c|c|c|}
\hline \multirow[b]{2}{*}{ Grupy form naczyń } & \multicolumn{4}{|c|}{ Strefy } & \multirow[b]{2}{*}{ R azem } \\
\hline & $\begin{array}{l}\text { zachodnia } \\
\text { (A/F) }\end{array}$ & $\begin{array}{c}\text { centralna } \\
\text { (B/E) }\end{array}$ & $\begin{array}{c}\text { R azem } \\
\text { zachodnia } \\
\text { i } \\
\text { centralna }\end{array}$ & $\begin{array}{l}\text { wschodnia } \\
\text { (C/D }\end{array}$ & \\
\hline Czteroelementowe z segmentową szyjką & 34 & 32 & 66 & 7 & 73 \\
\hline Trzyelementowe z wyodrębnioną szyjką & 2 & 1 & 3 & 1 & 4 \\
\hline Trzyelementowe bez szyjki & 16 & 15 & 31 & 2 & 33 \\
\hline Trzyelementowe z cylindryczną szyjką & 11 & 6 & 17 & 3 & 20 \\
\hline Dwuelementowe z szyjką (kubki/czarki) & 1 & & 1 & & 1 \\
\hline Jednoelementowe (doniczkowate) & 14 & 15 & 29 & 6 & 35 \\
\hline L iczna form & 78 & 69 & 147 & 19 & 166 \\
\hline \multicolumn{5}{|l|}{ Liczba naczyń } & 2778 \\
\hline
\end{tabular}


DOMNIEMANA KARCZMA WCZESNOŚREDNIOWIECZNA W KAŁDUSIE

Tabela 2. Kałdus, gm. Chełmno, woj. kujawsko-pomorskie, stanowisko 2. Domniemana karczma (obiekt 172). Skład taksonomiczny szczątków zwierzęcych oraz ich liczebność na tle wydzielonych działek badawczych A-F

\begin{tabular}{|c|c|c|c|c|c|}
\hline \multirow[b]{2}{*}{ Taksony } & \multicolumn{4}{|c|}{ Strefy } & \multirow[b]{2}{*}{ R azem } \\
\hline & $\begin{array}{c}\text { zachodnia } \\
\text { (A/F) }\end{array}$ & $\begin{array}{c}\text { centralna } \\
\text { (B/E) }\end{array}$ & \begin{tabular}{|c} 
Razem \\
zachodnia \\
i \\
centralna
\end{tabular} & $\begin{array}{c}\text { wschodnia } \\
\text { (C/D }\end{array}$ & \\
\hline Bydło - Bos primigenius $f$. taurus & 69 & 106 & 175 & 41 & 216 \\
\hline Świnia - Sus scrofa f. domestica & 60 & 91 & 151 & 29 & 180 \\
\hline Owca/koza - Ovis ammon f. aries/Capra aegagrus f. hircus & 38 & 47 & 85 & 16 & 101 \\
\hline Owca - Ovis ammon f. aries & 1 & 1 & 2 & & 2 \\
\hline Koza - Capra aegagrus f. hircus & 2 & & 2 & 1 & 3 \\
\hline Koń - Equus ferus f. caballus & 7 & 8 & 15 & 3 & 18 \\
\hline Pies - Canis lupus f. familiaris & & 1 & 1 & & 1 \\
\hline Kot - Felis silvestris $\mathrm{f}$. catus & & & & 1 & 1 \\
\hline Zając szarak - Lepus europaeus (Pall. 1778) & 4 & 1 & 5 & & 5 \\
\hline Wiewiórka - Sciurus vulgaris L. 1758 & & & & 1 & 1 \\
\hline Lis - Vulpes vulpes (L., 1758) & & 1 & 1 & & 1 \\
\hline Niedźwiedź brunatny - Ursus arctos L., 1758 & 2 & & 2 & & 2 \\
\hline Dzik - Sus scrofa L., 1758 & 5 & 3 & 8 & & 8 \\
\hline Jeleń - Cervus elaphus L., 1758 & 6 & & 6 & 3 & 9 \\
\hline Łoś - Alces alces (L., 1758) & & 1 & 1 & & 1 \\
\hline Sarna - Capreolus capreolus (L., 1758) & & 4 & 4 & 2 & 6 \\
\hline Ptaki-Aves & 6 & 19 & 25 & 6 & 31 \\
\hline Ryby - Pisces & 8 & 7 & 15 & 1 & 16 \\
\hline Rozpoznane & 208 & 290 & 498 & 104 & 602 \\
\hline Nierozpoznane & 77 & 134 & 211 & 24 & 235 \\
\hline Razem & 285 & 424 & 709 & 128 & 837 \\
\hline
\end{tabular}


Tabela 3. Kałdus, gm. Chełmno, woj. kujawsko-pomorskie, stanowisko 2. Domniemana karczma (obiekt 172).

Skład taksonomiczny szczątków roślinnych oraz ich liczebność na tle wydzielonych działek badawczych A-F

\begin{tabular}{|c|c|c|c|c|c|}
\hline \multirow[b]{2}{*}{ Taksony } & \multicolumn{4}{|c|}{ Strefy } & \multirow[b]{2}{*}{ Razem } \\
\hline & $\begin{array}{c}\text { zachodnia } \\
\text { (A/F) }\end{array}$ & $\begin{array}{c}\text { centralna } \\
\text { (B/E) }\end{array}$ & \begin{tabular}{|c|} 
Razem \\
zachodnia \\
i \\
centralna
\end{tabular} & $\begin{array}{l}\text { wschodnia } \\
\text { (C/D }\end{array}$ & \\
\hline Kąkol polny - Agrostemma githago & & 1 & 1 & 1 & 2 \\
\hline Owies zwyczajny - Avena cf. sativa & 5 & 1 & 6 & & 6 \\
\hline Stokłosa żytnia - Bromus secalinus & 2 & & 2 & & 2 \\
\hline Grab pospolity - Carpinus betulus & 3 & 3 & 6 & & 6 \\
\hline Zboża nieokreślone - Cerealia indet. & 15 & 16 & 31 & 15 & 46 \\
\hline Buławinka czerwona - Claviceps purpurea & 2 & & 2 & & 2 \\
\hline Leszczyna pospolita - Corylus avellana & 2 & 5 & 7 & 1 & 8 \\
\hline Motylkowate - Fabaceae & 1 & & 1 & & 1 \\
\hline Rdestówka powojowata - Fallopia convolvulus & 2 & & 2 & & 2 \\
\hline Jęczmień zwyczajny - Hordeum vulgare & & & & 1 & 1 \\
\hline Jęczmień - Hordeum sp. & 1 & & 1 & & 1 \\
\hline Soczewica jadalna - Lens culinaris & & 2 & 2 & 1 & 3 \\
\hline Len zwyczajny - Linum usitatissimum & 1 & & 1 & & 1 \\
\hline Proso zwyczajne - Panicum miliaceum & & 4 & 4 & 1 & 5 \\
\hline Groch zwyczajny - Pisum sativum & 35 & & 35 & 3 & 38 \\
\hline Trawy dzikie - Poaceae & & 4 & 4 & & 4 \\
\hline Śliwa lubaszka - Prunus insistitia & & 1 & 1 & & 1 \\
\hline Żyto zwyczajne - Secale cereale & 61 & 7 & 68 & 1 & 69 \\
\hline Pszenica zwyczajna - Triticum aestivum & 4 & 2 & 6 & 1 & 7 \\
\hline Pszenica - Triticum sp. & & & & 2 & 2 \\
\hline Wyka - Vicia sp. & 3 & & 3 & & 3 \\
\hline Nieokreślone - Indeterminate & 6 & 8 & 14 & 3 & 17 \\
\hline R azem & 143 & 54 & 197 & 30 & 227 \\
\hline
\end{tabular}




\section{Wykaz źródeł}

Anonim tzw. Gall, Kronika polska, przekład R. Grodecki, opracowanie M. Plezia, Wrocław 2003.

Kosmasa Kronika Czechów, przekład M. Wojciechowska, Warszawa 1968.

Cosmae chronicon Boemorum cum continuatoribus Kosmův letopis český (Kosmova kronika) s pokračovateli, Fontes rerum Bohemicarum. Tom II. Prameny dějin českých. Díl II, wyd. J. Elmer, V. V. Tomek, Praha 1874.

Galla Kronika, wyd. August Bielowski, (W:) M onumenta Poloniae Historica, t. 1, Lwów 1864, 379-484.

Kodeks Dyplomatyczny Wielkopolski, t. 1, wyd. I. Zakrzewski, Poznań 1877.

Pommerellisches Urkundenbuch, t. 1, wyd. M. Perlbach, Danzig 1882.

Preussisches Urkundenbuch, t. 1, wyd. R. Phillipi, C.P. Woelky, Königsberg 1882.

\section{Wykaz skrótów}

KDW - Kodeks Dyplomatyczny Wielkopolski

Mons - Mons Sancti Laurentii, red. W. Chudziak, Toruń

PUB - Preussisches Urkundenbuch

PomUB - Pommerellisches Urkundenbuch

\section{Literatura}

Abramów J. 2012. Roślinność w gospodarce mieszkańców ośrodka in Culmine na Pomorzu Nadwiślańskim we wczesnym średniowieczu (maszynopis w archiwum Instytutu Archeologii UMK w Toruniu). Toruń.

Andrzejewski A. 2013. Badania archeologiczno-architektoniczne, (W:) H. Karwowska, A. Andrzejewski (red.), Założenie rezydencjonalne Sapiehów w Dubnie. Białystok, 125-194.

Andrzejewski A., Karwowska H. 2013. Rekonstrukcja zespołu rezydencjonalnego, (W:) H. Karwowska, A. Andrzejewski (red.), Założenie rezydencjonalne Sapiehów w Dubnie. Białystok, 353-384.

Augustyniak J. 2014. Średniowieczne przeprawy przez Pilice $i$ ich obrona. Żarnowiec - Przedbórz - Sulejów - Inowtódz. Łódź.

Badura. M. 2009. Źródła archeobotaniczne do studiów nad gospodarką roślinną w strefie pogranicza polsko-pruskiego - wstępne wyniki. Acta Archaeologica Pomo- ranica 3. XVI Sesja Pomorzoznawcza, cz. 1. Szczecin, 403-410.

Bajburin A. 1990. W sprawie opisu struktury słowiańskiego rytuału budowniczego, Polska Sztuka Ludowa. Konteksty 44 (3), 62-69.

Baranowski B. 1979. Polska karczma: restauracja, kawiarnia. Wrocław.

Barciak A., Sepiał M. 2011. Ulice, place i cmentarze w przestrzennym rozwoju Raciborza w średniowieczu i w początkach nowożytności. (W:) S. Krabath, J. Piekalski, K. Wachowski (red.), Ulica, plac i cmentarz w publicznej przestrzeni średniowiecznego i wczesnonowożytnego miasta Europy Środkowej/Strasse, Platz und Friedhof in dem öffentlichen Raum der mittelalterlichen und frühneuzeitlichen Stadt Mitteleuropas, Wratislavia Antiqua 13. Wrocław, 51-61.

Barnycz-Gupieniec R. 2000. Studia nad drewnianym budownictwem $w$ średniowiecznej Polsce na tle porównawczym. Łowicz.

Barnycz-Gupieniec R. 2014. Typy konstrukcyjne budowli drewnianych w rejonie Morza Bałtyckiego we wczesnym średniowieczu. (W:) H. Paner, M. Fudziński, W. Świętosławski (red.), Pomorze we wczesnym średniowieczu w świetle źródel archeologicznych. Historia, stan aktualny i potrzeby badań. Gdańsk, 90-95.

Baron J. 2012. Ritual and cultural change. Transformations in rituals At the junction of pagan religion and Christianity in early medieval Poland. (W:) B. Gediga, A. Grossman, W. Piotrowski (red.), Rytm przemian kulturowych w pradziejach i średniowieczu. BiskupinWrocław, 449-462.

Bednarek R., Jankowski M., Kwiatkowska A., Markiewicz M., Świtoniak M. 2004. Rekonstrukcja dawnej pokrywy glebowej oraz jej przekształceń na terenie zespołu osadniczego w Kałdusie. (W:) Mons, t. 2, 185-197.

Behre K.E. 1992. The History of rye cultivation in Europe. Vegetation H istory and A rchaeobotany 1, 141-156.

Berezowski S. 1975. Zarys geografii komunikacji. Warszawa.

Bieniak J. 1970. Studia nad dziejami ziemi chełmińskiej w okresie piastowskim. Rocznik Grudziadzki 5-6, 5-69.

Bieniak J. 1996. Polska elita polityczna w XII wieku, cz. III B: Arbitrzy książąt - trudne początki. Społeczeństwo Polski średniowiecznej 7, 11-44.

Błędowski P., Chudziak W., Weinkauf M. 2007. Wczesnośredniowieczna osada podgrodowa i cmentarzysko 
szkieletowe w Kałdusie, gm. Chełmno, stanowisko 2 (badania 2004-2005). (W:) G. Nawrolska (red.), XV Sesja Pomorzoznawcza. Materiaty z konferencji 30 listopada-02 grudnia 2005. Elbląg, 249-261.

Bojanowska-Ziemska B. 1978. Lokalizacja karczem wiejskich w Polsce od końca XVIII do połowy XIX wieku. Politechnika Warszawska. Prace Naukowe: Budownictwo 59.

Bojarski J., Chudziak W., Weinkauf M. 2006. Z badań nad wczesnośredniowiecznym zespołem osadniczym w Kałdusie na Pomorzu Nadwiślańskim (lata 20002003). (W:) W. Chudziak, S. Moździoch (red.), Stan $i$ potrzeby badań nad wczesnym średniowieczem w Polsce - 15 lat później. Toruń-Wrocław-Warszawa, 369-382.

Bojarski J., Chudziak W., Weinkauf M. w druku a. Badania na terenie wczesnośredniowiecznego zespołu osadniczego w Bydgoszczy Fordonie (stanowisko 151 - dawny Wyszogród) w 2012 i 2013 roku. Acta Archaeologica Pomoranica.

Bojarski J., Chudziak W., Weinkauf M. w druku b. Wczesnośredniowieczna osada podgrodowa (stanowisko 2) w Kałdusie, woj. kujawsko-pomorskie. Badania w latach 2012-2013. Acta Archaeologica Pomoranica.

Bojarski J., Weinkauf M. 2011. Wczesnośredniowieczna osada w Kałdusie, woj. kujawsko-pomorskie, (stanowisko 2). Wstępne wyniki badań prowadzonych w latach 2007-2009. (W:) M. Fudziński i H. Paner (red.), XVII Sesja Pomorzoznawcza. Od epoki kamienia do wczesnego średniowiecza, t. 1. Gdańsk, 499-512.

Boroń P. 1997. Problem dużych budynków halowych na terenie Słowiańszczyzny zachodniej w IX-X wieku. (W:) K. Wachowski (red.), Ślask i Czechy a kultura wielkomorawska. Wrocław, 31-49.

Buczek K. 1964. Targi i miasta na prawie polskim. Wrocław.

Burghardt A.F. 1971. A Hypothesis About Gateway Cities. Annals of the Association of American Geographers 59, 269-285.

Chmielewski T.J. 2009. Po nitce do ktębka .... o przędzalnictwie i tkactwie młodszej epoki kamienia w Europie Środkowej. Warszawa.

Christaller W. 1963. Ośrodki centralne w Południowych Niemczech. (W:) J. Kostrowicki (red.), Teoria ośrodków centralnych. Przegląd Zagranicznej Literatury Geograficznej 1, 1-72.

Chudziak W. 1997. Dalekosiężne szlaki komunikacyjne w strefie chełmińsko-dobrzyńskiej w X-XI wieku. (W:) OJ A. Spież OP, Z. Wielgosz (red.), Benedyktyńska praca. Studia historyczne ofiarowane o. Pawłowi
Szczanieckiemu OSB $w 80$ rocznice urodzin. Tyniec, 101-118.

Chudziak W. 2003. Wczesnośredniowieczna przestrzeń sakralna in Culmine na Pomorzu Nadwiślańskim. (W:) Mons, t. 1.

Chudziak W. 2010. Chełmno/Kulm - Genese und Funktion einer frühmittelalterlichen Stadt. Acta Praehistorica et Archaeologica 42, 19-40.

Chudziak W., Bojarski J. 2014. Stan badań nad wczesnym średniowieczem na Pomorzu Nadwiślańskim. Badania Instytutu Archeologii UMK w Toruniu. (W:) M. Fudziński, H. Paner (red.), Z dziejów badań archeologicznych na Pomorzu Wschodnim. Gdańsk, 109-132.

Chudziak W., Weinkauf M. 2009. Wczesnośredniowieczna osada podgrodowa w Kałdusie (województwo kujawsko-pomorskie), stanowisko 2 (badania w latach 20052007). (W:) A. Janowski. K. Kowalski, S. Sowiński (red.), Acta Archaeologica P omoranica 3, 281-291.

Cieśla I. 1958. Taberna wczesnośredniowieczna na ziemiach polskich. Studia Wczesnośredniowieczne 4, 158-222.

Constable O.R. 2004. Housing the Stranger in the Mediterranean World. Lodging, Trade and Travel in Late Antiquity and the Middle Ages. Cambridge.

Cooley Ch.H. 1894. The Theory of Transportation. Publications of the American Economic Association 9, 13-148.

Dąbkowski P. 1914. Przewóz wodny. Studium z historii prawa polskiego. Rozprawy Akademii Umiejętności 57, Wydziat Historyczno-Filozoficzny, Seria II, t. 32, 196-301.

Dąbrowska M. 1971. Ogrzewanie i oświetlenie wnętrz mieszkalnych na ziemiach polskich w VI-XIII w. Kwartalnik Historii Kultury Materialnej 19, nr 3, 369398.

Dembińska M. 1978a. Funkcje targu, wymiana i moneta. (W:) M. Dembińska, Z. Podwińska (red.), Historia kultury materialnej Polski w zarysie, t. I (od VII do XII w.). Wrocław-Warszawa-Kraków-Gdańsk, 252-263.

Dembińska M. 1978b. Pożywienie. (W:) M. Dembińska, Z. Podwińska (red.), Historia kultury materialnej Polski w zarysie, t. I (od VII do XII wieku). Wrocław-Warszawa-Kraków-Gdańsk, 289-299.

Drozd A. 2006. Wyposażenie grobowe na wczesnośredniowiecznych cmentarzyskach plaskich z terenu Polski jako element praktyk funeralnych 2 (maszynopis w archiwum Instytutu Archeologii UMK w Toruniu). Toruń.

Drury P.J. 1988. The Mansio and other Sites in the SouthEastern Sector of Caesaromagus. Council for British Archaeology Report 67, London. 
Dulinicz M. 1987. Wczesnośredniowieczne stosunki osadnicze. (W:) J. Pyrgała (red.), Osadnictwo obszaru Warszawy na tle środowiska naturalnego $V$ w. p.n.e. - XII w. n.e. Wrocław-Warszawa-Kraków-GdańskŁódź, 117-139.

Dunin-Wąsowicz T. 1975. Komunikacja i transport w węźle warszawskim. (W:) A. Gieysztor (red.), Studia Warszawskie, t. 19, Warszawa średniowieczna, z. 2. Warszawa, 107-109.

Filipowiak W. 1993. Słowiańskie wierzenia pogańskie u ujścia Odry. (W:) M. Kwapiński, H. Paner (red.), Wierzenia przedchrześcijańskie na ziemiach polskich. Gdańsk, 19-46.

Filipowiak W. 2003. Wolin - most na przeprawie? (W:) T. Galiński, E. Wilgocki (red.), Res et Fontes. Księga jubileuszowa dr. Eugeniusza Cnotliwego. Szczecin, 143-158.

Gloger Z. 1910. Encyklopedia staropolska ilustrowana 3. Warszawa.

Grodecki R. 1921. Mincerze we wcześniejszym średniowieczu polskim. Rozprawy Akademii Umiejętności, t. 63, Wydziat Historyczno-Filozoficzny, Seria II, t. 38, 77-132.

Gupieniec R. 1999. Budownictwo wczesnośredniowieczne w źródłach pisanych. Mazowieckie Studia Humanistyczne 5/2, 5-11.

Guldon Z., Powierski J. 1974. Podziały administracyjne Kujaw i ziemi dobrzyńskiej w XIII-XIV wieku. Warszawa-Poznań.

Hensel W. 1958. Poznań w zaraniu dziejów: od paleolitu do połowy XIII wieku n. e. Wrocław.

Hensel W. 1987. Słowiańszczyzna wczesnośredniowieczna. Zarys kultury materialnej. Warszawa.

Jesch J. 2008. Geography and Travel. (W:) R. McTurk (red.), A Companion to Old Norse-Islandic Literature and Culture. Oxford, 119-135.

Jóźwiak S. 1996. Translokacje Chełmna a powstanie komturstw staro- i nowochełmińskiego. (W:) R. Czaja, J. Tandecki (red.), Studia nad dziejami miast i mieszczaństwa w średniowieczu., t. 2, Studia ofiarowane Profesorowi Antoniemu Czacharowskiemu w sześćdziesiata piata rocznice urodzin $i$ czterdziestolecie pracy naukowej. Toruń, 83-94.

Kalinowski S. 2007. Wczesnośredniowieczny budynek drewniany z osady podgrodowej w Katdusie (stanowisko 2), (maszynopis w archiwum Instytutu Archeologii UMK w Toruniu). Toruń.

Karpińska A. 1935. Poznań-Sołacz jako osada wczesnohistoryczna. Kronika Miasta Poznania 13 (nadbitka).

Kaźmierczyk J. 1993. Ku poczatkom Wrocławia. Cz. 2. Warsztat budowlany i kultura mieszkalna Ostrowa
Tumskiego od połowy XI do połowy XIII wieku. Wrocław.

Kiersnowski R. 1990. Niedźwiedzie i ludzie $w$ dawnych $i$ nowszych czasach. Fakty i mity. Warszawa.

Klichowska M. 1972. Rośliny naczyniowe w znaleziskach kulturowych Polski północno-zachodniej. Prace Komisji Biologicznej 35, z. 6, 1-73.

Kóčka-Krenz H. 1993. Biżuteria pótnocno-zachodnio-słowiańska we wczesnym średniowieczu. Poznań.

Kola A. 1975. Wczesnośredniowieczne Chetmno w świetle źródel archeologicznych. Problem pierwotnej lokalizacji, część I-II, (maszynopis w archiwum Instytutu Archeologii UMK w Toruniu). Toruń.

Komorowo. 1999. Komorowo. Stanowisko 12: osadnictwo nowożytne (XVII-XVIII w.). Ślady domniemanej karczmy, T. Malinowski (red.), Zielona Góra.

Kordowski J. 2004. Osady i rzeźba doliny Wisły w okolicach Chełmna i Świecia. (w:) Mons, t. 2, Toruń, 43-68.

Kostrzewski J. 1962. Kultura prapolska. Warszawa.

Kowalczyk M. 1986. Raciaż - średniowieczny gród i kasztelania na Pomorzu w świetle źródeł archeologicznych i pisanych. Archaeologia Baltica 6, Łódź.

Kozłowski T. 2012. Stan biologiczny $i$ warunki życia ludności in Culmine na Pomorzu Nadwiślańskim (X-XIII wiek): studium antropologiczne. (W:) Mons, t. 7. Toruń.

Kromer M. 1853. Polska, czyli o położeniu, obyczajach, urzędach Rzeczypospolitej Królestwa Polskiego. Wilno.

Krzysztofik R. 2004. Miasta-wrota. Zarys teorii i przegląd badań. Czasopismo Geograficzne 75, 13-231.

Krzyżanowski W. 1957. Zagadnienia teoretyczno-ekonomiczne geografii transportu. Przeglad Geograficzny 29, 287-315.

Kucypera P. 2009. Technika dziwerowania wczesnośredniowiecznych głowni mieczowych. Inżynieria Powierzchni 3, 44-49.

Labuda G. 1978. Początki klasztoru w świetle źródeł pisanych. (W:) Materiaty sprawozdawcze z badań zespołu pobenedyktyńskiego w Mogilnie, t. 1, Biblioteka Muzealnictwa i Ochrony Zabytków, seria B, t. 52.

Lalik T. 1965. Regale targowe książąt wschodniopomorskich w XII-XIII wieku. Przegląd

Historyczny 56, z. 2, 171-201.

Le Goff J. 2002. Kultura średniowiecznej Europy. GdańskWarszawa.

Lityńska-Zając M. 1997. Środowisko i uprawa roślin w czasach pra- i wczesnohistorycznych. (W:) K. Tunia (red.), Z archeologii Małopolski. Historia i stan badań zachodniomałopolskiej wyżyny lessowej. Kraków, 459-482. 
Lityńska-Zając M. 2010. Flora Stradowa we wczesnym średniowieczu - wyniki badań archeobotanicznych. (W:) A. Buko, M. Lityńska-Zając (red.), Stradów: wczesnośredniowieczny zespół osadniczy, t. 2, Materiaty archeobotaniczne $i$ archeozoologiczne z badań na stanowisku 1 w latach 1956-1963. Polskie Badania Archeologiczne 37, 27-47.

Lityńska-Zając M., Makowicz-Poliszot D., Tyniec A., Szmoniewski B.Sz., Wołoszyn M. 2010. Stradów. Studium archeologiczno-przyrodnicze wczesnośredniowiecznego zespołu osadniczego. (W:) A. Buko, M. Lityńska-Zając (red.), Stradów: wczesnośredniowieczny zespót osadniczy, t. 2, Materiały archeobotaniczne $i$ archeozoologiczne z badań na stanowisku 1 w latach 1956-1963. Polskie Badania Archeologiczne 37, 113-142.

Łoziński W. 1978. Życie polskie $w$ dawnych wiekach. Kraków.

Makowiecki D. 2003. Historia ryb i rybołówstwa $w$ holocenie na Niżu Polskim $w$ świetle badań archeoichtiologicznych. Poznań.

Makowiecki D. 2004. Zwierzęce szczatki kostne z Kałdusa, stan. 2A, gm. Chetmno (sezon 2004). Zestawienia tabelaryczne. Rokietnica (maszynopis w archiwum Instytutu Archeologii UMK w Toruniu).

Makowiecki D. 2010. Wczesnośredniowieczna gospodarka zwierzętami i socjotopografia in Culmine na Pomorzu Nadwiślańskim. Studium archeozoologiczne. (W:) Mons, t. 6.

Malinowski T. 1999. Próba podsumowania wyników badań. (W:) Komorowo, 109-113.

Matuszewska-Kola W. 1972. Badania archeologiczne wczesnośredniowiecznej osady podgrodowej w Kałdusie, pow. Chełmno, w 1957 roku. Acta Universitatis Nicolai Copernici. Archeologia 3, z. 45, 95-124.

McGrail S. 1985. Early Landing Places. (W:) A. E. Herteig (red.), Conference on Waterfront Archaeology in North European Towns No. 2 Bergen 1983. Bergen, 12-18.

Modzelewski K. 2000. Organizacja gospodarcza państwa piastowskiego X-XIII wiek. Poznań.

Mons. 2006. Wczesnośredniowieczne cmentarzysko szkieletowe w Katdusie (stanowisko 1). (W:) Mons, t. 3.

Mons.2010. Wczesnośredniowieczne cmentarzysko szkieletowe w Katdusie (stanowisko 4). (W:) Mons, t. 5.

Moździoch S. 1990. Organizacja gospodarcza państwa wczesnopiastowskiego na Ślasku. Studium archeologiczne. Wrocław-Warszawa-Kraków.

Moździoch S. 2013. Życie codzienne średniowiecznego Polaka w świetle odkryć archeologicznych, czyli roz- paczliwa próba udowodnienia, że nam dzisiaj żyje się lepiej. (W:) M. Brzostowicz, M. Przybył, J. Wrzesiński (red.), Wioski i parafie w średniowieczu: wykłady popularno-naukowe zorganizowane $w$ ramach $I X \mathrm{Fe}$ stiwalu Kultury Stowiańskiej $i$ Cysterskiej w Ladzie nad Warta w dniach 8-9 czerwca 2013 roku. PoznańLąd, 104-128.

Munby et al. 1992. Zacharias's: a $14^{\text {th }}$-century Oxford New Inn and the Origins of the Medieval Urban Inn. Oxonensia 57, 245-309.

Musianowicz K. 1950. Chata z podcieniem w osadzie podgrodowej w Bródnie Starym, pow. warszawski. Sprawozdania Państwowego Muzeum Archeologicznego 3, z. 1-2, 175-184.

Naumowiczówna E. 1961.Wczesnośredniowieczna osada w Zgniłce, pow. Sępólno Krajeńskie. Fontes Archaeologici Posnaniensis 12, 220-241.

Nowak Z.1987. Dzieje Chełmna do końca XVIII wieku. (W:) M. Biskup (red.), Dzieje Chetmna i jego regionu. Warszawa-Poznań-Toruń, 63-128.

Ojdana A. M. 2012. Nowożytne szkło z karczmy w Dubnie (gmina Boćki, woj. podlaskie). Toruń (maszynopis w archiwum Instytutu Archeologii UMK w Toruniu).

Page R.I. 2014. Chronicles of the Vikings. Records, Memorials and $\mathrm{M}$ yths. London.

Pauk M.R. 2015. Radix omnium malorum: taberny i pijaństwo w tzw. statutach księcia czeskiego Brzetysława I. (W:) G. Rutkowska, A. Gąsiorowski (red.), M emoria viva. Studia historyczne poświęcone pamięci Izabeli Skierskiej (1967-2014). Warszawa-Poznań, 88-99.

Pearce J. 2000. Late $18^{\text {th }}$-century Inn Clearance Assemblages from Uxbridge, Middlesex. Post-Medieval Archaeology 34, 144-186.

Gastfreundschaft. 1983. Gastfreundschaft, Taverne und Gasthaus im Mittelalter, red. H. C. Peyer. Schriften des Historischen Kollegs 3, München-Wien.

Peyer H.C. 1987. Von der Gastfreundschaft zum Gasthaus. Studien zur Gastlichkeit im Mittelalter. Monumenta Germanica Historica Schriften 31, Hannover.

Piaskowski J. 1974. O stali damasceńskiej. Wrocław-Warszawa-Kraków-Gdańsk.

Piskorski J.M. 2005. Miasta księstwa szczecińskiego do połowy XIV wieku. Poznań-Szczecin.

Polcyn M. 2004. Pozaekonomiczny aspekt źródeł paleoetnobotanicznych na przykładzie obiektu 4/98 z grodziska w Kałdusie, stanowisko 3. (W:) Mons, t. 2, 231-243.

Powierski J. 1996. Prusowie, Mazowsze i sprowadzenie Krzyżaków do Polski, t. 1. Malbork. 
Pryžov I.G. 1868. Istoriâ kabakov v Rossii v svâzi s istoriej russkago naroda. Moskva.

Pytlak P. 2013. Domniemana późnośredniowieczna karczma $w$ Strzelcach Krajeńskich (woj. lubuskie). Toruń (maszynopis w archiwum Instytutu Archeologii UMK w Toruniu).

Pytlak M., Pytlak P. 2014. Domniemana średniowieczna karczma w Strzelcach Krajeńskich. Materiały z badań archeologicznych. Archeologia Środkowego Nadodrza 11, 107-145.

Rabęcka-Brykczyńska I. 1964. Karczma. (W:) W. Kowalenko, G. Labuda, T. Lehr-Spławiński (red.), Słownik Starożytności Stowiańskich. Encyklopedyczny zarys kultury Stowian od czasów najdawniejszych do schytku wieku XII, t. II. Wrocław-Warszawa-Kraków, 373-375.

Robak Z. 2009. Wczesnośredniowieczny wóz w Polsce. Zbornik Filozofickej Fakulty Univerzity Komenského 26, 175-188.

Rogosz R. 1983 Obróbka i zastosowanie żelaza. (W:) E. Cnotliwy, L. Leciejewicz, W. Łosiński (red.), Szczecin we wczesnym średniowieczu: Wzgórze Zamkowe. Wrocław, 262-267.

Samsonowicz A. 2011. Łowiectwo w Polsce Piastów i Jagiellonów. Warszawa.

Samsonowicz H. 1954. Rzemiosło wiejskie w Polsce XIV$X V I w$. Badania z Dziejów Rzemiosła i Handlu w Epoce Feudalizmu 2. Warszawa.

Samsonowicz H. 1974. Handel dalekosiężny na ziemiach polskich w świetle najstarszych taryf celnych. (W:) S. Herbst (red.), Społeczeństwo, gospodarka, kultura. Studia ofiarowane M. Małowistowi w czterdziestolecie pracy naukowej. Warszawa, 289-302.

Siemianowska E. 2014. O zastosowaniu niektórych modeli teoretycznych w badaniach nad ośrodkami miejskimi w średniowieczu. Archaeologia H istorica Polona 22, 27-54.

Sławski F. 1958. Słownik etymologiczny języka polskiego, t. 2, z. 1. Kraków.

Sobociński M. 1977. Surowce zwierzęce. Elementy anatomii i fizjologii zwierzat domowych. Wrocław-Warszawa.

Söderlind U. 2007. What was served at the Koffsan Inn during the $18^{\text {th }}$ century? (W:) U. Fransson, M. Svedin,
S. Bergerbrant, F. Androshchuk (red.), Cultural interaction between east and west. Archaeology, artefacts and human contacts in Northern Europe. Stockholm, 302-306.

Stanisławski B. 2011. Budownictwo wczesnośredniowiecznego Wolina - próba reinterpretacji. Materiały Zachodniopomorskie. Seria nowa 6/7, 223-268

Suchanecka K. 2011. Kronika muzealna 2001-2009. Rocznik Muzeum Mazowieckiego w Płocku 19, 235-300.

Szmańda J. B., Lankauf K. R., Luc M. 2004. Próba rekonstrukcji zmian rzeźby Góry św. Wawrzyńca i fazy jej rozwoju. (W:) Mons, t. 2, 177-183.

Szurowa B. 1978. Karczmy na Kielecczyźnie w XVIII i XIX wieku. Kielce.

Trawkowski S. 1962. Taberny płockie na przełomie XI i XII wieku. W sprawie zakresu obrotu towarowo-pieniężnego. Przegląd Historyczny 53, z. 4, 731-744.

Trawkowski S. 1985. Życie osiadłe. (W:) J. Dowiat (red.), Kultura Polski średniowiecznej X-XIII w. Warszawa, 96-116.

Waluś A., Manasterski D. 1999. Uwagi na temat krzemieniarstwa w grupie środkowopolskiej kultury łużyckiej w młodszym okresie epoki brązu. Światowit 1 (42)/ Fasc. B, 207-212.

Weinkauf M. 2005. Wczesnośredniowieczna osada podgrodowa w Kałdusie, gm. Chełmno, stanowisko 2 (badania 2002-2003). (W:) H. Paner, M. Fudziński (red.), XIV Sesja Pomorzoznawcza. Od wczesnego średniowiecza do czasów nowożytnych, t. 2. Gdańsk, 119-134.

Weinkauf M. 2006. Narzędzia. (W:) Mons, t. 3, 84-104.

Wessén E., Jansson S. 1953-57. Upplands runinskrifter 4. Stockholm.

Wiklak H. 1959a. Prace ratowniczo-wykopaliskowe w Kałdusie pow. Chełmno. Wiadomości Archeologiczne 26, z. 3-4, 329.

Wiklak H. 1959b. Osada wczesnośredniowieczna w Kałdusie pow. Chełmno. Wiadomości Archeologiczne 26, z. 3-4, 330-331.

Zaremska H. 1997. Miejsca spotkań kultury masowej: karczmy i łaźnie. (W:) B. Geremek (red.), Kultura Polski średniowiecznej XIV-XV w. Warszawa, 628668. 


\title{
THE SUPPOSED INN FROM EARLY MEDIEVAL SETTLEMENT COMPLEX IN KAŁDUS ON POMERANIA VISTULA
}

\begin{abstract}
SUMMARY
Inns played a special role in the social and cultural sphere of early medieval Europe. They were one of the main elements of communications infrastructure of the time. Diplomatic sources from the Slav lands, dated back to the $13^{\text {th }}$ and $14^{\text {th }}$ centuries, most often described the inn with a Latin term taberna or a Slavic word korczma, presenting it as an already fully formed and organized institution. Among many references to inns from the area of Poland appearing in written sources, one refers in explicit terms to early medieval Chełmno (today village Kałdus). Among incidences of taxes for the Benedictine monastery in Mogilno appears the "ninth" (nona tax) with a fee from the inn in Chełmno, in the original: In Culmine nonum forum cum tabernario (KDW I, 3). In the course of systematic field excavations conducted in 2003 in the north-western part of the immediately adjacent to a fortified centre, ancillary settlement in Kałdus (site 2), in the highest part of the settlement, about 20-30 meters from the alleged gateway to the fortified part, a construction marked with number 172 was discovered, associated with the youngest stage of the settlement, i.e. the second half of the $12^{\text {th }}$ and the first half of the $13^{\text {th }}$ century.

In the light of the results of the analysis taking into account the formal characteristics of the feature 172, the specificity of the set of movable objects found within the feature, historical and settlement context, the construction can be interpreted as remains of a supposed inn. The most important premises that justify this view include: a) location of the "In Culmine" settlement complex directly at the crossing over the Vistula River, at an important junction connecting the most important long-distance routes in the region; b) the location of the feature on a slight rise, directly at the communications route leading towards the

crossing over the Vistula River, near the gate leading to the castellan fortified centre; c) a unique size of the building with reference to the whole ancillary settlement, allowing to perform many social, economic and political functions; d) specific post-and-plank construction with arcades, distinguishing the building from standard buildings of the settlement; e) concentration of economic and productive facilities related to the building, signifying that it was the centre of a large farmstead, within which activities related to services, exchange and various types of production were conducted (numerous merchant utensils, coins, artefacts connected with magic and entertainment, etc.); f) a set of archaeobotanical (corn) and archaeozoological (domestic and wild animals, fish) sources; g) the existence of an earlier, multiphase building (feature 240) in this place, indicating a "long tradition" of using of this point in space, which is consistent with the principle of long duration of communications infrastructure.

The building interpreted as an inn should be considered a unique object with reference to constructions of western Slav lands. It would be the first discovery of an inn from Poland of so early chronology, certified by a number of sources data that may provide indicators to identify such objects. Locating it in the immediate vicinity of the fortified settlement, which combined administrative, political and religious functions, seems to be the most reasonable and logical. The fact is confirmed by the Mogilno forgery, in which the existence of the market and the inn is mentioned in explicit terms. Certainly, it is difficult to categorically combine the historical record about the inn with the remains of the discovered building. However, in light of the presented facts, it seems that such a conclusion is significantly probable.
\end{abstract}

Adres Autorów:

Prof. dr hab. Wojciech Chudziak, Dr Marcin Weinkauf, Mgr Ewelina Siemianowska,

Dr Jacek Bojarski, Mgr Barbara Kowalewska, Dr Paweł Szczepanik,

Dr Joanna Abramów, Mgr Dorota Bienias, Prof. dr hab. Daniel Makowiecki

Instytut Archeologii

Uniwersytet Mikołaja Kopernika w Toruniu

ul. Szosa Bydgoska 44/48

87-100 Toruń 